ReseArCH ArTiCle

Published May 14, 2021

\title{
COVID-19 Outcomes in Patients Undergoing B Cell Depletion Therapy AND ThOSE WITH Humoral IMMUNODEFICIENCY STATES: A SCOPINg Review
}

\section{AUTHORS}

Jessica M. Jones ${ }^{1}$ (ORCID ID: 0000-0002-9005-228X), Aiman J. Faruqi ${ }^{1}$ (ORCID ID: 0000-00024421-3767), James K. Sullivan ${ }^{1}$ (ORCID ID: 0000-0001-5853-1590), Cassandra Calabrese ${ }^{2}$ (ORCID ID: 0000-0002-8773-7739), Leonard H. Calabrese ${ }^{2}$ (ORCID ID: 0000-0002-1789-4923)

\section{AFFILIATED INSTITUTIONS}

${ }^{1}$ Cleveland Clinic Lerner College of Medicine of Case Western Reserve University, Cleveland, Ohio

${ }^{2}$ Cleveland Clinic, Department of Rheumatic and Immunologic Diseases, Cleveland, Ohio

\section{CORRESPONDING AUTHOR}

Leonard H. Calabrese, DO

Cleveland Clinic, Cleveland, $\mathrm{OH}$

calabrl@ccf.org

ORCID: 0000-0002-1789-4923

\section{SUGGESTED CITATION}

Jones JM, Faruqi AJ, Sullivan JK, Calabrese C, Calabrese LH. Pathogens and Immunity. 2021;6(1):76-103. doi:10.20411/pai.v6i1.435

\section{ABSTRACT}

Background: The role of humoral immunity has been well established in reducing infection risk and facilitating viral clearance in patients with COVID-19. However, the relationship between specific antibody responses and severity of COVID-19 is less well understood. 
Methods: To address this question and identify gaps in knowledge, we utilized the methodology of a scoping review to interrogate risk of infection and clinical outcomes of COVID-19 in patients with iatrogenic and inborn humoral immunodeficiency states based on existing literature.

Results: Among patients with iatrogenic B-cell depletion, particularly with agents targeting CD20, our analysis found increased risk of severe COVID-19 and death across a range of underlying disease states. Among patients with humoral inborn errors of immunity with COVID-19, our synthesis found that patients with dysregulated humoral immunity, predominantly common variable immunodeficiency (CVID), may be more susceptible to severe COVID-19 than patients with humoral immunodeficiency states due to X-linked agammaglobulinemia and other miscellaneous forms of humoral immunodeficiency. There were insufficient data to appraise the risk of COVID-19 infection in both populations of patients.

Conclusions: Our work identifies potentially significant predictors of COVID-19 severity in patients with humoral immunodeficiency states and highlights the need for larger studies to control for clinical and biologic confounders of disease severity.

Keywords: COVID-19; B-cell; inborn errors of immunity; Scoping Review; Antibodies, CD20

\section{INTRODUCTION}

The host immune response to SARS-CoV-2 infection is complex and involves integration of both innate and humoral limbs $[\underline{1}, \underline{2}]$. Much attention has been focused on humoral immunity with attempts to define its clinical importance in both protecting the host from infection as well in resolving disease $[\underline{2}, \underline{3}]$. Clinical evidence supporting the effectiveness of humoral immunity to SARS-CoV-2 in these tasks include the therapeutic effects of monoclonal antibodies in facilitating the clearance of virus, particularly in those with suboptimal baseline humoral responses [4], and the strong correlation between the presence of baseline natural antibody status and reduced risk of reinfection [ $[$ ]. The development of neutralizing antibodies has also been correlated with protection of de novo infection in those successfully immunized [6]. Less clear, however, is the role of specific antibody responses in recovery from COVID-19, as most investigations have demonstrated higher antibody levels in those with more severe forms of disease [ 7 ], suggesting that neutralizing antibodies may have a relatively limited impact on disease resolution.

Dissecting the precise role of humoral immunity to a viral infectious agent is daunting given that specific antibodies play numerous and interrelated roles within the integrated immune defense network $[\underline{8}, \underline{9}]$. Beyond their capacity to block viral entry, antibodies provide defense by interacting with complement and Fc receptors on a wide variety of cells; these functions have been linked to resolution of many infectious diseases [10-15]. Under other circumstances, however, specific antibodies can enhance pathology [16], and thus understanding this balance is important as we craft more effective therapeutics and vaccines.

Among the tools to help dissect and analyze the physiologic role of specific components of the immune response in humans is the examination of clinical settings where there are selective deficiencies and appraising the outcomes in the interactions with pathogens. These deficiencies can be primary, as observed in patients with inborn errors of immunity (IEI) or iatrogenic as in patients who are treated with targeted therapies directed against discrete components of the immune response [17]. The aim of this scoping review is to systematically map the empiric evidence 
regarding the severity of COVID-19 in patients with these deficiency states as well as to identify any existing gaps in knowledge. Scoping reviews are a type of knowledge synthesis that follow specific methodology to summarize concepts, trends, gaps, and the variety of studies in a given field [18]. A scoping review was identified as the most appropriate method of knowledge synthesis as it was anticipated we would encounter substantial heterogeneity of study populations within these 2 broad categories as well as variability of reporting of immunologic data and outcomes. This review was designed to inform the field about the relative importance of humoral immunity in the integrated defense network with the prospects for better managing and counseling of patients so afflicted as well as providing insights into therapeutic development.

\section{METHODS}

We utilized the methodology of a scoping review in order to investigate our overarching research question: "How do innate or iatrogenic deficiencies in humoral immunity impact clinical outcomes from COVID-19?" We followed the guidelines of Preferred Reporting Items for Systemic Reviews and Meta-Analyses Extension for Scoping Reviews (PRISMA-ScR) as outlined by Tricco et al [18].

\section{Eligibility criteria}

Eligible studies included English-language literature related to COVID-19 and patients who received B-cell depleting therapies or with humoral inborn errors of immunity (hIEI). Within the iatrogenic B-cell depletion category of our literature search, the decision was made to include case reports and case series in order to obtain a higher degree of information about patient outcomes within each medication group than could be obtained within the larger cohort studies. In contrast, for the hIEI literature search, case reports, small-scale literature reviews, and cohort studies were included to identify all unique patients to date given the small population of hIEI patients who were infected with SARS-CoV-2.

\section{Information sources}

For iatrogenic B-cell depletion articles, an initial PubMed search was conducted on November 18, 2020 for articles on COVID-19 (Concept 1, Supplemental data) outcomes in patients receiving CD19- and CD20-targeting medications (Concept 2, Supplemental data). Throughout the process of reviewing papers, relevant references within initial search results were also identified and included. During the writing process, select authors within the field also directed us to unpublished results. For hIEI articles, we conducted a PubMed search for articles on COVID-19 (Concept 1, Supplemental data) outcomes in patients with hIEIs through March 24, 2021. Keywords for hIEIs were systematically chosen using the 2019 Update of the IUIS Phenotypical Classification of Predominantly Antibody Deficiencies (Concept 3, Supplemental data). A final PubMed search was performed for all concepts on March 25, 2021, newly reported series within the iatrogenic subgroup, and single reports within the IEI subgroup were then analyzed and incorporated where appropriate.

\section{Selection of sources of evidence}

All articles were first screened by title and abstract for relevance, and studies not meeting inclusion criteria were removed. Studies were then reviewed in full, and mined for type of article, and reported outcomes. 


\section{Data charting process and data items}

For all included studies, the highest level of care (outpatient, hospital ward, intensive care unit [ICU]) and clinical outcome (recovery or death) were tabulated. Parameters unique to iatrogenic B-cell depletion articles that were charted included specific B-cell depleting therapy, time from last infusion, duration of symptoms, and serology status after recovery. Levels of B cell, IgG, and IgM prior to infection were also queried, but were missing in the majority of papers and so were not included in the final report. Parameters unique to hIEI articles that were charted included demographic information (age, sex), specific diagnosis or genetic mutation, and comorbid medical conditions.

\section{RESULTS}

\section{Selection and characteristics of sources of evidence}

Our iatrogenic B-cell depletion search yielded 103 results. Twelve articles were removed after being deemed unrelated through screening of title and abstract. An additional 40 articles were excluded for wrong study type or irrelevant outcomes. The final analysis consisted of 51 studies: 14 cohort studies and 37 small case series or case reports. Our hIEI search yielded 66 results. Opinion articles, ecologic studies, and articles unrelated to COVID-19 hIEI clinical outcomes were excluded. Eleven articles were included for final analysis including 6 case reports [19-24], 4 cohort studies [드-28] , and 1 literature review of case reports [29]. Duplicate patient reports across studies were accounted for, and only patients with clearly defined hIEIs from cohort studies were included. Table 1 lists a summary of the papers included in this scoping review by condition studied.

Table 1: Summary of papers included within Scoping Review

\begin{tabular}{|l|c|c|}
\hline Condition Studied & Number of studies & Number of patients \\
\hline Rheumatologic & 9 & 348 \\
\hline Multiple Sclerosis or related & 20 & 2,951 \\
\hline Hematologic & 10 & 24 \\
\hline Nephrotic & 3 & 161 \\
\hline Vasculitis & 9 & 9 \\
\hline hIEI & 11 & 82 \\
\hline Totals: & 62 & 3,575 \\
\hline
\end{tabular}

Section A. Do patients with compromised humoral immunity from iatrogenic B-cell depletion therapy have greater risk of COVID-19 infection compared to the general population?

\section{Epidemiologic studies of incidence without comparators}

Six studies ( 4 in patients with multiple sclerosis [MS], 1 in a patient with rheumatic disease, and 1 in a patient with pediatric nephrotic syndrome) identified the incidence of SARS-CoV-2 infection among patients receiving B-cell depleting therapies (Table 2). The incidence rates of 4 of these studies ranged from 0-33\%, and all data was collected between April and May of 2020. None of 
the studies provided direct comparisons to incidence rates within the general population at the time of the study data collection.

\section{Epidemiologic studies of incidence of SARS-CoV-2 infection with comparators}

Two studies of patients with multiple sclerosis compared patients with B-cell depletion therapy risk of SARS-CoV-2 infection to patients with the same disease not receiving B-cell depleting therapies (Table 2). Both studies found an increased risk of infection among their patients receiving B-cell depleting therapies compared to those not receiving B-cell depleting therapies [ $\underline{30}$, 31]. No studies of patients with rheumatic disease or nephrotic syndrome included a comparator group not receiving B-cell depletion therapy.

Two additional studies in persons with multiple sclerosis (PwMS) reported comparisons between rates of anti-CD20 use among SARS-CoV-2 positive and negative patients. A retrospective study in Italy of 844 PwMS with suspected $(n=565)$ or confirmed $(n=279)$ COVID-19 found that PwMS with a suspected or confirmed SARS-CoV-2 infection were treated with ocrelizumab at a significantly higher frequency than the general Italian PwMS population ( $\mathrm{OR}=1.84,95 \%$ CI 1.31-2.56) [32]. Similarly, a study from New York of SARS-CoV-2 positive/suspect positive PwMS noted a relatively high proportion of SARS-CoV-2 infected patients receiving anti-CD20 therapies (44.7\%) compared with their PwMS population, in which $33.1 \%$ of patients take anti-CD20 therapies [33]. Although these studies are limited by lack of appropriate comparison groups and adjustments for potential confounding variables, they nevertheless suggest that iatrogenic B-cell depletion may increase risk of COVID-19 infection at least within certain disease groups.

Section B: Are patients with compromised humoral immunity at risk for more severe outcomes from COVID-19 than patients with functioning humoral systems?

\section{latrogenic B-cell depletion - Effects on COVID-19 disease severity}

Through case reports, we identified 54 individual cases of COVID-19 among patients receiving anti-CD20 medications (Supplementary Table). Among this cohort, 57\% were hospitalized (31/54), 20\% were treated as outpatients (11/54), 19\% were treated in the ICU (10/54), and 4\% did not report a severity level (2/54). Average duration of symptoms was 28.8 days.

Among case series assessing severity (Table 3), 4 clinical case series ( 2 in PwMS and 2 in patients with rheumatic disease) examined the severity of COVID-19 among patients receiving B-cell depleting therapies compared to patients not receiving B-cell depleting therapies. Odds ratio of severe infection ranged from $2.37(1.18-4.74)$ [32] and 4.34 (1.77-10.63) [34] compared to patients with the same disease not receiving B-cell depleting therapies. Among studies examining patients with rheumatic disease, a recent series from a French registry of patients found, using multivariable analysis, that rituximab use was associated with an increased risk of severe infection (defined as requiring ICU admission or death) compared to mild or moderate (defined as requiring hospital admission) ( $\mathrm{OR}=4.34,1.77-10.63)$ [34]. Among this same cohort, a later study utilizing propensity scoring to adjust for confounders found that rituximab users more frequently had severe disease, $(\mathrm{OR}=3.26,95 \% \mathrm{CI} 1.66-6.40)$ and longer duration of hospital stay (HR=0.62, CI 0.460.85 ) than non-rituximab users [35]. Among the studies of PwMS, Sormani et al [32] found an increased risk of severe disease (defined as developing at least 1 of death, ICU admission, diagnosis of pneumonia, or hospitalization) among patients receiving the anti-CD20 agents ocrelizumab or 
rituximab compared to PwMS with COVID-19 not receiving B-cell depleting therapies, adjusting for likely cofactors that could affect disease outcome $(\mathrm{OR}=2.37,1.18-4.74)$ [르. A North American cohort of PwMS found that even after adjusting for confounders, patients receiving rituximab had 4.5-fold increased odds of hospitalization for COVID-19 (2.10-9.90) but no change in ICU or ventilatory support need, compared with those not taking any disease modifying therapy (DMT). Furthermore, ocrelizumab also increased odds of hospitalization, but to a lesser degree $(\mathrm{OR}=1.63$, $.98-2.72)[\underline{36}]$.

In terms of variables reflecting disease severity, death is the most specific. Ten case series were identified that provided mortality rates among patients receiving CD20 depleting therapies with COVID-19 or suspected COVID-19 (Tables 2 and 3). Among these, 5 studies focused on PwMS, 4 on patients with rheumatic diseases, and 1 on a patient with cancer (Tables 2 and 3 ). The number of patients receiving B-cell depleting drugs in these series ranged from 3 to 1858 and the mortality ranged from 0 to $33 \%$ (Tables 2 and 3).

Table 2: Incidence of COVID-19 among patients receiving CD20 depleting drugs

\begin{tabular}{|c|c|c|c|c|c|c|c|c|}
\hline Disease & Drug & \# Pts. & $\begin{array}{l}\text { Infec- } \\
\text { tion } \\
\text { rate }\end{array}$ & $\begin{array}{c}\text { Relative } \\
\text { risk/odds } \\
\text { ratio } \\
\text { (Infection) }\end{array}$ & $\begin{array}{l}\text { Mortality } \\
\text { rate }\end{array}$ & $\begin{array}{c}\text { How positivity } \\
\text { was determined }\end{array}$ & $\begin{array}{c}\text { Date of } \\
\text { data } \\
\text { extraction }\end{array}$ & Ref. \\
\hline \multicolumn{9}{|c|}{ Studies not including a comparison group } \\
\hline $\begin{array}{l}\text { Multiple } \\
\text { Sclerosis }\end{array}$ & Rituximab & 54 & $\begin{array}{c}7 \\
(12.9 \%) \\
\end{array}$ & & 0 & \multirow[t]{2}{*}{ Symptoms } & \multirow[t]{2}{*}{ Apr-20 } & \multirow[t]{2}{*}[\underline{73}]{} \\
\hline $\begin{array}{l}\text { Multiple } \\
\text { Sclerosis }\end{array}$ & Ocrelizumab & 6 & $2(33 \%)$ & & 0 & & & \\
\hline $\begin{array}{l}\text { Multiple } \\
\text { Sclerosis }\end{array}$ & Ocrelizumab & 6 & 0 & & & Patient interview & Apr-20 & {$[\underline{74}]$} \\
\hline $\begin{array}{l}\text { Pediatric } \\
\text { Nephrotic } \\
\text { Syndrome }\end{array}$ & Anti CD20 & 159 & 0 & & & Symptoms & Apr-20 & {$[\underline{75}]$} \\
\hline $\begin{array}{l}\text { Rheumato- } \\
\text { logic Diseases }\end{array}$ & Rituximab & 76 & $\begin{array}{c}13 \\
(17.1 \%)\end{array}$ & & $3(23.1 \%)$ & Symptoms & May-20 & {$[\underline{76}]$} \\
\hline \multicolumn{8}{|c|}{ Studies including a comparison group } & \\
\hline $\begin{array}{l}\text { Multiple } \\
\text { Sclerosis }\end{array}$ & Rituximab & 285 & $\begin{array}{c}21 \\
(7.4 \%) \\
\end{array}$ & \multirow{2}{*}{$\begin{array}{l}\text { RR: } 3.55 \\
(\mathrm{CI}: 1.45, \\
8.68)^{\mathrm{a}}\end{array}$} & & \multirow[t]{2}{*}{ Symptoms } & \multirow[t]{2}{*}{ Apr-20 } & \multirow[t]{2}{*}[\underline{30}]{} \\
\hline $\begin{array}{l}\text { Multiple } \\
\text { Sclerosis }\end{array}$ & Ocrelizumab & 12 & 0 & & & & & \\
\hline $\begin{array}{l}\text { Multiple } \\
\text { Sclerosis }\end{array}$ & Rituximab & 1858 & $\begin{array}{c}38 \\
(2.0 \%) \\
\end{array}$ & $\begin{array}{l}\text { OR:1.85 (CI: } \\
1.37-2.33)^{\mathrm{b}} \\
\end{array}$ & $2(5.3 \%)$ & \multirow{2}{*}{$\begin{array}{c}\text { Positive } \\
\text { PCR result or } \\
\text { compatible lung } \\
\text { CT scan }\end{array}$} & \multirow[t]{2}{*}{ May-20 } & \multirow[t]{2}{*}{ [31] } \\
\hline $\begin{array}{l}\text { Multiple } \\
\text { Sclerosis }\end{array}$ & Ocrelizumab & 24 & $\begin{array}{c}1 \\
(4.2 \%)\end{array}$ & $\begin{array}{l}\mathrm{OR}=2.83 \\
\quad(\mathrm{CI}: \\
.81-4.84)^{\mathrm{b}} \\
\end{array}$ & 0 & & & \\
\hline
\end{tabular}

a compared to patients receiving non-cell depleting, non-cell trafficking inhibitor disease modifying therapies

${ }^{\mathrm{b}}$ compared to patients with same disease receiving non-B cell depleting therapies 
Table 3: Mortality Rate among COVID-19+ patients receiving B-cell depleting therapies

\begin{tabular}{|c|c|c|c|c|c|c|c|}
\hline Disease & Drug & \# Pts. & $\begin{array}{l}\text { Mortality } \\
\text { rate }\end{array}$ & $\begin{array}{c}\text { Odds Ratio } \\
\text { (Risk of } \\
\text { mortality) }\end{array}$ & $\begin{array}{l}\text { How positivity was } \\
\text { determined }\end{array}$ & $\begin{array}{l}\text { Date of data } \\
\text { extraction }\end{array}$ & Ref. \\
\hline \multicolumn{8}{|c|}{ Studies without a comparison group for mortality } \\
\hline $\begin{array}{l}\text { Rheumatic } \\
\text { Diseases }\end{array}$ & Anti CD20 & 3 & $1(33 \%)$ & & Unknown & Unknown & {$[\underline{77}]$} \\
\hline $\begin{array}{l}\text { Rheumatic } \\
\text { Diseases }\end{array}$ & Rituximab & 7 & $1(14.3 \%)$ & & $\begin{array}{c}\text { Nasopharyngeal } \\
\text { swabs or symptoms } \\
\text { with compatible lung } \\
\text { imaging and/or posi- } \\
\text { tive serology }\end{array}$ & Jun-20 & {$[\underline{78}]$} \\
\hline $\begin{array}{l}\text { Multiple } \\
\text { Sclerosis }\end{array}$ & Anti CD20 & 34 & $2(5.9 \%)$ & & Health care provider & Apr-20 & {$[\underline{33}]$} \\
\hline $\begin{array}{l}\text { Multiple } \\
\text { Sclerosis }\end{array}$ & Rituximab & 5 & $1(20 \%)$ & & \multirow[t]{2}{*}{ Symptoms } & \multirow[t]{2}{*}{ May-20 } & \multirow[t]{2}{*}[\underline{32}]{} \\
\hline $\begin{array}{l}\text { Multiple } \\
\text { Sclerosis }\end{array}$ & Ocrelizumab & 83 & $1(1.2 \%)$ & & & & \\
\hline Cancer & Anti CD20 & 14 & $1(7.1 \%)$ & & SARS-CoV2 RT-PCR & Apr-20 & [79] \\
\hline \multicolumn{8}{|c|}{ Studies including a comparison group for mortality } \\
\hline $\begin{array}{l}\text { Rheumatic } \\
\text { Diseases }\end{array}$ & Rituximab & 192 & $42(21.9 \%)$ & $\begin{array}{c}\mathrm{OR}=4.04 \\
(2.32-7.03)^{\mathrm{a}}\end{array}$ & Physician Report & Jul-20 & [37] \\
\hline $\begin{array}{l}\text { Rheumatic } \\
\text { Diseases }^{\mathrm{b}}\end{array}$ & Rituximab & $34 / 63$ & $\begin{array}{l}7(20.6 \%) \\
/ 13(21 \%)\end{array}$ & $\begin{array}{c}\mathrm{OR}=4.04 \\
\left(1.35-12.04^{\mathrm{c}}\right. \\
/ \mathrm{OR}=1.32 \\
(0.55-3.19)^{\mathrm{d}}\end{array}$ & Physician Report & $\begin{array}{l}\text { May-20/ } \\
\text { Nov-20 }\end{array}$ & $\begin{array}{l}{[\underline{34}] /} \\
{[\underline{35}]}\end{array}$ \\
\hline $\begin{array}{l}\text { Multiple } \\
\text { Sclerosis }\end{array}$ & Rituximab & 77 & $3(3.9 \%)$ & $\begin{array}{c}\mathrm{OR}=2.81 \\
(0.45-17.70)^{\mathrm{e}} \\
\end{array}$ & \multirow[t]{2}{*}{ Physician Report } & \multirow[t]{2}{*}{ Dec-20 } & \multirow[t]{2}{*}[\underline{36}]{} \\
\hline $\begin{array}{l}\text { Multiple } \\
\text { Sclerosis }\end{array}$ & Ocrelizumab & 484 & $11(9.1 \%)$ & $\begin{array}{c}\mathrm{OR}=0.47 \\
(0.17-1.30)^{+}\end{array}$ & & & \\
\hline
\end{tabular}

a Compared to patients taking methotrexate

b Two studies using the same cohort were identified. Each study sample and findings are reported within this row.

c Cannot determine how the comparison group was defined. Adjusted for age and sex

d Compared to non-rituximab users. Propensity score weighted adjustment for multiple covariates.

e Compared to no disease modifying therapy. Multivariable multinomial logistic regression model adjusting for age, sex, race, ambulation, cigarette smoking, glucocorticoid use, comorbidities, and DMTs.

Two studies of rheumatic diseases incorporated multivariable logistic regression analysis and a comparator group to assess risk of mortality among those with rheumatic disease receiving B-cell depleting therapy (Table 3) $[\underline{34}, \underline{37}]$. In the French registry, the odds ratio for death among patients receiving rituximab compared to a matched control group was elevated $(4.04,1.35-12.04)$ [34]. This cohort was reanalyzed in a later study with a larger sample size using propensity scoring and found that the adjusted risk of death was not significantly increased in the rituximab group compared to non-rituximab users ( $\mathrm{OR}=1.32,95 \% \mathrm{CI} 0.55-3.19)$ [ㅌ5]. In the largest study of pa- 
tients with rheumatic disease and COVID-19, the Global Rheumatology Alliance analyzed 3729 patients (192 of whom were receiving rituximab) and found rituximab carried the highest odds of death compared to patients taking methotrexate monotherapy in both unadjusted and adjusted multivariable logistic regression models $(\mathrm{OR}=4.04,2.32-7.03)$ [37].

The North American Registry by Salter et al also looked at mortality among PwMS receiving B-cell depleting therapies. They found no statistically significant difference in risk of mortality between patients receiving rituximab or ocrelizumab therapy compared to patients not receiving DMT after multivariable adjustment [36]. Thus, based upon these data, even with their inherent limitations, it appears that iatrogenic B-cell depletion may be associated with both increased risk of severe disease and risk of mortality among patients both with rheumatic disease as well as MS.

\section{latrogenic B-cell depletion - Effects on response to COVID-19 therapies}

At time of writing, only a single study was found investigating treatment for COVID-19 infection specifically for B-cell depleted patients. Seventeen patients receiving B-cell depleting therapy (nearly all of whom had a profound hypogammaglobulinemia associated with an absence of circulating B cells, and none had mounted a neutralizing antibody response after several weeks of symptoms) were treated with convalescent plasma, which led to striking improvement of clinical symptoms and biological parameters in 16 out of 17 patients and a decrease of SARS-CoV-2 RNAemia within 7 to 14 days, highlighting the potential importance of circulating antibodies in infection clearance [료].

\section{Humoral Inborn Errors of Immunity - Effects on COVID-19 disease severity}

Our search identified 82 unique patients (34\% female) with hIEIs and confirmed SARS-CoV-2 infection from across the globe (Table 4). The majority of patients (49) had common variable immunodeficiency (CVID) [19, 22-29]. Fifteen patients had agammaglobulinemia (12 X-linked, 3 autosomal recessive) [21, 25-29]. Six patients had hyper-IgM disease [25, 27, 28]. Five patients had specific immunoglobulin deficiencies (IgG, IgA, or both) [20, 25-27]; 4 patients had otherwise unspecified hypogammaglobulinemia [25, 26]; 2 patients had antibody deficiency with syndromic features [26]; and 1 patient had activated PI3K delta syndrome (APDS) [26]. The age distribution of the cohort ranged from pediatric patients to the elderly ( $>75$ years), though patients with agammaglobulinemia were younger on average than their CVID counterparts (no patient older than 54). Mean age could not be calculated due to incomplete data.

The risk of SARS-CoV-2 infection among patients with hIEI remains incompletely understood, as most studies examined clinical outcomes in hIEI patients with confirmed SARS-CoV-2 infection rather than incidence of infection. However, 1 large cohort study of 4718 patients with primary immunodeficiencies (PIDs) in Iran, including 1001 with hIEIs alive during the pandemic, found 19 confirmed cases of SARS-CoV-2 infection, with 4 cases among hIEI patients. Overall, the incidence of infection in this PID cohort was only 1.23-fold higher than the general population. Importantly, as the authors noted, the external validity of this may be limited due to pediatric skew of the cohort as well as increased precautions taken by patients with PIDs [27]. 
Table 4: Clinical Outcomes in Patients with hIEI and with Confirmed COVID-19

\begin{tabular}{|l|c|c|c|c|c|c|c|l|}
\hline $\begin{array}{l}\text { Immuno- } \\
\text { deficiency }\end{array}$ & $\begin{array}{c}\text { \# of } \\
\text { Patients } \\
\text { (\# Females) }\end{array}$ & $\begin{array}{c}\text { Age } \\
\text { Range }\end{array}$ & $\begin{array}{c}\# \\
\text { Out- } \\
\text { patient }^{*}\end{array}$ & $\begin{array}{c}\text { \# Hospital } \\
\text { Ward }^{*}\end{array}$ & $\begin{array}{c}\# \\
\text { ICU }^{*}\end{array}$ & $\begin{array}{c}\# \\
\text { Recovered }\end{array}$ & $\begin{array}{c}\# \\
\text { Died }\end{array}$ & Ref. \\
\hline CVID & $49(21)$ & 8 to $75+$ & 20 & 17 & 12 & 41 & 8 & {$[\underline{19}, \underline{22}-\underline{29}]$} \\
\hline XLA & $12(0)$ & 5 to 54 & 3 & 9 & 0 & 12 & 0 & {$[\underline{25}-\underline{29}]$} \\
\hline ARA & $3(0)$ & 35 to 64 & 2 & 0 & 1 & 3 & 0 & {$[\underline{25}, \underline{26}]$} \\
\hline $\begin{array}{l}\text { Hypogamma } \\
\text { unspecified }\end{array}$ & $4(3)$ & 3 to $75+$ & 2 & 1 & 1 & 3 & 1 & {$[\underline{25}, \underline{26}]$} \\
\hline Ig Deficiency & $5(2)$ & 8 to $75+$ & 1 & 1 & 3 & 3 & 2 & {$[\underline{20}, \underline{25}, \underline{26}]$} \\
\hline HIGM & $6(1)$ & 6 to 30 & 4 & 2 & 0 & 6 & 0 & {$[\underline{25}, \underline{27}, \underline{28}]$} \\
\hline $\begin{array}{l}\text { Syndromic Ab } \\
\text { deficiency }\end{array}$ & $2(0)$ & $3-12 ; 35$ & 0 & 1 & 1 & 1 & 1 & {$[\underline{26}]$} \\
\hline APDS PIK3R1 & $1(1)$ & $25-35$ & 1 & 0 & 0 & 1 & 0 & {$[\underline{26}]$} \\
\hline TOTAL & $82(28)$ & & 33 & 31 & 18 & 70 & 12 & \\
\hline
\end{tabular}

CVID: Common Variable Immunodeficiency; XLA: X-linked Agammaglobulinemia; ARA: Autosomal Recessive Agammaglobulinemia; HIGM: Hyper-IgM Syndrome; APDS PIK3R1: Activated Phosphoinositide 3-Kinase $\delta$ Syndrome

Within the CVID cohort (43\% female) identified by our search, 12 patients $(24.5 \%)$ required intensive care. Seventeen patients were hospitalized without intensive care, and the 20 remaining patients were either asymptomatic or received outpatient care only. Treatment regimens varied from supportive care only to aggressive multidrug regimens of antibiotics, steroids, and immunomodulatory agents. Patient comorbidities also varied significantly, from none to chronic lung, liver, endocrine, cardiovascular, and kidney disease. In total, 8 (16.3\%) CVID patients died, 7 of them female. Among 15 CVID patients without notable comorbidities, 1 died, and among 7 patients age 65 or older, 2 died [19, 22-29] termed coronavirus disease 2019 (COVID-19).

Among 15 agammaglobulinemia patients (100\% male), 1 patient required intensive care, 9 patients were hospitalized without intensive care, and 5 patients were either asymptomatic or received outpatient care only. Treatment varied from supportive care only to convalescent plasma infusions, antibiotics, and immunomodulatory agents. Strikingly, although nearly half (7) of these patients had pre-existing comorbid lung disease (eg, COPD, bronchiectasis), all of them recovered from COVID-19 [리 $\underline{25}-\underline{29}]$.

Based on these limited data, it appears that patients with dysregulated humoral immune responses, such as CVID, may be more susceptible to severe COVID-19 than patients with ostensibly more severe, but select, humoral immunodeficiency states characterized by agammaglobulinemia. 


\section{DISCUSSION}

To the best of our knowledge, this scoping review is the first attempt to analyze and synthesize the role of humoral immunity in COVID-19 infection across a spectrum of clinical disorders caused by iatrogenic B-cell depletion and inborn errors of immunity. We believe our observations have potentially important implications for understanding the network of host defense against SARSCoV-2, but have significant limitations in their strength, as will be discussed.

Defining the precise role of humoral immunity in the integrated defense against SARS-CoV-2 infection is problematic and incompletely understood. Antibodies (specifically IgG, IgM, and $\operatorname{IgA}$ ) have long been recognized as important components of adaptive immune defense and protection in respiratory viral infections, particularly in influenza and other human coronaviruses $[\underline{8}, \underline{10}$, 13]. In COVID-19, there is now clear evidence that a SARS-CoV-2 specific antibody response is important during the early stages of infection, evidenced by the strong correlation between antibody response to vaccine and protection from incident and severe infections in non-human primate studies $[\underline{39}, \underline{40}]$, the effectiveness of monoclonal antibodies [1] $]$ and convalescent plasma [42] early in infection, and the correlation between the neutralizing antibody seroconversion and multiple log reduction in viral load in cases of uncomplicated infection in humans [41].

The role of specific antibodies in later stages of the infection is less clear, as most patients with advanced forms of COVID-19 have higher viral loads than those with mild and early disease despite higher levels of antibodies with neutralizing capacity $[\underline{43}, \underline{44}]$. Further, the same monoclonal antibody therapy effective at controlling infectious spread early in COVID-19 is not effective in later stages of disease []].

The results of our scoping review provide insights from 2 disease models that both share deficits of humoral immune responsiveness: (1) iatrogenic depletion of B cells with biologic therapies and (2) primary inborn errors of immunity with explicit humoral defects. Each provides some degree of insight into the role of antibodies against SARS CoV-2.

From our examination of COVID-19 in patients with IEIs, we found no studies of adequate design to assess whether patients are more susceptible to SARS-CoV-2 infection. Largely from detailed individual case reports and small series (Table 4), we did appraise evidence documenting recovery from SARS-CoV-2 infection without a significant antibody response. This evidence confirms a major role for cell-mediated immunity in infection resolution [ㅍ5] and is consistent with numerous reports of recovery in healthy individuals without generating detectable antibody response $[\underline{7}, \underline{46}]$.

Within the IEI spectrum, our review supports a general trend for greater morbidity and mortality among patients with CVID than patients with X-linked agammaglobulinemia (XLA), an observation previously made by others $[\underline{26}, \underline{29}, \underline{47}]$. The reasons for this differential disease severity between these subsets of IEI are unclear but several factors deserve comment. First, CVID is a highly heterogenous immune deficiency disorder which, by definition, includes defective humoral immune function, but often is attended by variable defects within the cell- mediated immune compartment as well $[\underline{48}, \underline{49}]$.

In contrast, patients with XLA display defective B-cell maturation with relatively preserved T-cell function as reflected by relatively preserved ex vivo responses to respiratory viruses [미]. Severe 
COVID-19 disease is often accompanied by a state of hyperinflammation, raising the question of whether patients with CVID, who are also at elevated risk of dysregulated inflammatory and granulomatous reactions [ $\underline{51}-\underline{53}$ ], may be predisposed to such immunodysregulation. In CVID, cellular abnormalities in T-cell compartments (ie, reduced T- regulatory cells [Tregs] and increased T-follicular helper cells [Tfh], along with perturbations of B-cell subsets and increases in innate lymphoid type 3 cells) may all contribute to immunodysregulation and promote a hyperinflammatory milieu $[\underline{54}, \underline{55}]$.

An additional mechanistic explanation for the favorable survival rate among those with XLA may be related to the expression of Bruton's Tyrosine Kinase (BTK) in macrophages and its role in TLR-mediated NF- $k$ B triggering of the production of multiple cytokines incriminated in the hyperinflammatory phase of COVID-19 [6] . Based on this rationale, the covalent inhibitor of BTK acalbrutinib has been used in a small open-label trial of 19 patients with severe COVID-19 demonstrating some degree of clinical success as well as ex vivo evidence of elevated BTK activity [57]. Detailed investigations attempting to understand the immunopathogenesis of COVID-19 in patients with humoral immunodeficiency states to date have been limited, but a recent study performing comprehensive flow cytometry examining subsets of $\mathrm{T}$ and $\mathrm{B}$ cells in a single patient with CVID and an immunocompetent control who both recovered from COVID-19 revealed a series of often contrasting abnormalities in both T-cell and B-cell compartments between experimental subjects [58]. The remaining forms of humoral IEI encountered in our review are too rare to draw any further conclusions regarding outcomes, though 13/17 (76\%) with these miscellaneous conditions did survive (Table 4).

Lastly, the patients with CVID included in this review tended to be older and had a greater burden of comorbidities, such as chronic lung disease. As we were unable to adjust for demographic differences between these 2 cohorts in this scoping review due to non-uniform reporting, it is possible these factors, particularly age, also underlie the observed differences in COVID-19 severity and survival. Consistent with this, a recent study from the United Kingdom demonstrated better outcomes in XLA patients, with zero reported deaths among 4 patients (mean age 30 years), compared to CVID patients, with 8 reported deaths among 23 patients (mean age 54 years) [ㄷ4] However, our observation that all agammaglobulinemia patients with comorbid lung disease recovered from COVID-19 suggests that the stark differences in outcomes between CVID and agammaglobulinemia patients may at least be partially attributable to immunologic determinants and cannot be entirely explained by comorbidities. Additional work, including the establishment of detailed prospective registries for the hIEI population capturing demographics, immunologic variables, and comorbidities will be needed to further clarify this issue.

Our review of patients with iatrogenic B-cell depletion also revealed no studies of sufficient rigor to assess whether patients receiving such therapies are more predisposed to SARS-CoV-2 infection. In terms of disease severity in patients with iatrogenic B-cell depletion states, our review suggests that such patients are at a higher risk for severe outcomes, including death, across underlying disease states (ie, rheumatic disorders, multiple sclerosis) (Tables 2 and 3). Although severe outcomes can potentially be attributed to numerous associated variables, such as underlying disease states, comorbidities, age, and other therapies, our review identified several studies of large numbers of patients $[\underline{32}, \underline{34}, \underline{37}]$ where multivariable analysis to control for such confounding was performed, adding weight to the idea that iatrogenic B-cell depletion itself may be driving risk. 
Though the registries on which these data are based are limited by reporting bias and low granularity of data collection, these effects merit continued monitoring as patient registries grow.

While conclusions of increased risk of severe COVID-19 with B-cell depletion are cautionary, they raise a number of questions as to what may underlie these biologic effects. Patients receiving B-cell depleting therapies are well documented to be at risk for serious infections [59], but the effects differ across indications (rheumatic, MS, hematologic etc.) [으-62]. Among our reported studies of COVID-19 infection, mortality and severity rates varied among different diseases. Whether quantitative or functional deficits of immunoglobulins contributed to these effects is of interest, but levels were not reported in the cohort studies included in our analysis. A recent report from the Roche/Genentech clinical trial data of PwMS treated with ocrelizumab found that, among those with COVID-19 with previous serum immunoglobulin levels reported (27/51, $52.9 \%)$, all had IgG levels within the normal range [63].

This finding should be regarded with caution due to the small sample size and lack of statistical modeling. However, in general, immunoglobulin levels are usually normal, even in the setting of long-term B-cell depleting therapies, though approximately $25 \%$ may ultimately have reduced levels of 1 or more immunoglobulin isotype [무]. Furthermore, it is well established that patients treated with B-cell depleting therapy have compromised humoral immunity with profound peripheral B-cell depletion, generally lasting 6-9 months or longer [64]. Unfortunately, B-cell levels were not reported in the majority of studies reviewed, and we were unable to analyze the direct correlation between B-cell levels and COVID-19 infection. Additionally, patients receiving B-cell depleting therapies experience impairments in their ability to generate normal antibody responses to a variety of vaccine challenges (ie, T-cell dependent, T-cell independent, and neoantigens) [ㄷ4-66], yet can generate cell-mediated immune responses to the recombinant zoster vaccine [67]. How patients undergoing B-cell depletion therapy will respond to COVID-19 vaccines is a particularly pressing issue; prospective studies examining humoral and cellular responses as well as tracking clinical effectiveness of vaccination to SARS-CoV-2 among this population are urgently needed.

The conclusions of this scoping review should be considered in the context of its limitations. For both categories of humoral immune deficiency reviewed, a lack of granularity and completeness of data including demographics, co-morbidities, immunologic data, and inconsistent definitions of severe COVID-19 were problematic. In particular, the reports in patients receiving B-cell depleting agents were essentially devoid of critical immunologic data such as immunoglobulin levels and B-cell numbers. We attempted to bridge this gap through case reports, but we were unable to consistently report immunoglobulin or B-cell levels in these patients. Another particularly important consideration within this patient population is timing of infection in relationship to last treatment. This latter point is of particular importance given the pharmacokinetics and pharmacodynamics of B-cell depleting monoclonal antibodies on B-cell depletion and reconstitution, and thus such data are critical for understanding the putative effects on COVID-19 outcomes. In their Italian PwMS population, Sormani et al discovered no association between COVID-19 severity and the time passed since the last anti-CD20 infusion (OR=2.77, 95\% CI 1.31-5.89 for last infusion within 3 months and $\mathrm{OR}=2.05,95 \%$ CI $0.97-4.28$ for last infusion before 3 months). Interestingly, they did report a trend of increased severity with increased duration of anti-CD20 therapy [32]. An analysis of the French Registry rituximab cohort found that reduced time from last infusion to COVID-19 infection was associated with more severe disease and higher risk of death [프] . 
Another limitation of most of the reported series of patients receiving B-cell depleting agents was a lack of well-defined comparison groups and inconsistent definitions of severe COVID-19, thus limiting our ability to interpret their potential confounding effects in these patient populations (eg, age, other pulmonary comorbidities) on outcomes. Thus, more robust studies, prospectively collected with larger sample sizes and comparator groups as well as detailed case reports with more comprehensive immune response profiles are needed to identify the risk of severe disease and mortality due to COVID-19 in these patient populations and to uncover possible pathophysiologic mechanisms.

In terms of the population with hIEIs, these are rare diseases and the prevalence of primary hIEIs is low, so the number of patients included in our scoping review was limited. While many of the other hIEIs described in table 4 (such as HIGM) present an intriguing course of COVID-19, with the majority recovering without admittance to the ICU, these studies did not uniformly report on comorbidities, concomitant treatments (such as Ig replacement therapy), or specific gene mutations, and had no comparator group, representing significant potential confounders in the interpretation of clinical outcomes in this unique cohort of patients. Lastly, we were cognizant of the potential for duplicate patients in our literature search and removed apparent duplicates from the hIEI case report summary table, and reported results from the iatrogenic case reports separately from cohort studies. However, it is still possible some of the trends identified were augmented by duplicate reports.

Finally, it should be noted that this review limited its scope to immunodeficiency states primarily compromising the humoral compartment. Therefore, other immunodeficiency states attended by humoral deficits that may affect COVID-19 clinical outcomes were not evaluated. Among these other diseases and corresponding immunodeficiency states, HIV infection deserves specific comment given the significant public health implications in relationship to COVID-19 [68]. HIV was not included in our analysis as it principally targets the T-cell compartment, and we did not consider HIV patients on highly active anti-retroviral therapy (HAART) to be immunocompromised. Nevertheless, it is well established that HIV also causes B-cell dysfunction [ $\underline{69}$ ], and further studies are warranted to interrogate its impact on COVID-19 clinical outcomes.

The implications of this scoping review are several. First, from several sources, we have confirmed that some patients with profound inherited and acquired deficits of humoral immunity may recover form COVID-19, but certain subgroups of these patients may be vulnerable to more severe outcomes. As described previously $[\underline{70}, \underline{71}]$ the likelihood that patients given B-cell depleting therapies will make any meaningful humoral response to COVID-19 vaccination is low, in light of their suppressed response to other T-cell dependent vaccines even when administered at their pharmacodynamic nadir [64]. However, it is unknown whether such patients can develop cellmediated immune responses to COVID-19 vaccinations and whether such response will confer significant protection. Thus, studies examining humoral and cellular vaccine responses as well as the effects of timing vaccine administration relative to drug administration are urgently needed. The same questions apply to patients with humoral IEI. While approximately $20 \%$ of patients with CVID taking immunoglobulin replacement may serologically respond to influenza vaccine [72], the majority do not; the response to COVID-19 vaccination in patients with IEI merits future study. In total, the disease course of COVID-19 in patients with humoral immune deficiencies provides insight into both the role of humoral- and cell- mediated arms of the adaptive immune 
system in SARS-CoV-2 infection.

\section{POTENTIAL CONFLICTS OF INTEREST/COMPETING INTERESTS}

Leonard H. Calabrese, DO, receives fees as a consultant to Genentech-Roche. The remaining authors have no relevant financial or non-financial interests to disclose.

\section{AUTHORS' CONTRIBUTIONS}

L. Calabrese and C. Calabrese developed the original idea for the article. Literature search and data analysis were performed by J. Jones, A. Faruqi, and J. Sullivan. All authors were involved in the drafting and critical revisions of the work.

\section{SUPPLEMENTARY DATA}

Supplementary materials are available at the Pathogens and Immunity website. Supplementary data may be provided by the authors to benefit the reader. Supplementary data are not copyedited and are the sole responsibility of the authors. Questions or comments related to supplementary materials should be addressed to the corresponding author.

Supplementary Methods

\section{FUNDING}

This work was supported by The R J Fasenmyer Center for Clinical Immunology Research Endowment.

\section{REFERENCES}

1. Ahmad T, Chaudhuri R, Joshi MC, Almatroudi A, Rahmani AH, Ali SM. COVID-19: The Emerging Immunopathological Determinants for Recovery or Death. Front Microbiol. 2020;11:588409. doi: 10.3389/fmicb.2020.588409. PMCID: PMC7736111 PMID: 33335518

2. Moderbacher CR, Ramirez SI, Dan JM, Grifoni A, Hastie KM, Weiskopf D, Belanger S, Abbott RK, Kim C, Choi J, Kato Y, Crotty EG, Kim C, Rawlings SA, Mateus J, Tse LPV, Frazier A, Baric R, Peters B, Greenbaum J, Saphire EO, Smith DM, Sette A, Crotty S. Antigen-Specific Adaptive Immunity to SARS-CoV-2 in Acute COVID-19 and Associations with Age and Disease Severity. Cell [Internet]. Elsevier; 2020 Sep 16 [cited 2020 Oct 10];0(0). doi: 10.1016/j.cell.2020.09.038. Available from: https:// www.cell.com/cell/abstract/S0092-8674(20)31235-6 PMID: 33010815

3. Zohar T, Alter G. Dissecting antibody-mediated protection against SARS-CoV-2. Nat Rev Immunol. 2020 Jul;20(7):392-394. doi: 10.1038/s41577-020-0359-5. PMCID: PMC7278217 PMID: 32514035

4. ACTIV-3/TICO LY-CoV555 Study Group, Lundgren JD, Grund B, Barkauskas CE, Holland TL, Gottlieb RL, Sandkovsky U, Brown SM, Knowlton KU, Self WH, Files DC, Jain MK, Benfield T, Bowdish ME, Leshnower BG, Baker JV, Jensen J-U, Gardner EM, Ginde AA, Harris ES, Johansen IS, Markowitz N, Matthay MA, Østergaard L, Chang CC, Davey VJ, Goodman A, Higgs ES, Murray DD, Murray TA, Paredes R, 
Parmar MKB, Phillips AN, Reilly C, Sharma S, Dewar RL, Teitelbaum M, Wentworth D, Cao H, Klekotka P, Babiker AG, Gelijns AC, Kan VL, Polizzotto MN, Thompson BT, Lane HC, Neaton JD. A Neutralizing Monoclonal Antibody for Hospitalized Patients with Covid-19. N Engl J Med. 2021 Mar 11;384(10):905-914. doi: 10.1056/ NEJMoa2033130. PMCID: PMC7781100 PMID: 33356051

5. Lumley SF, O'Donnell D, Stoesser NE, Matthews PC, Howarth A, Hatch SB, Marsden BD, Cox S, James T, Warren F, Peck LJ, Ritter TG, de Toledo Z, Warren L, Axten D, Cornall RJ, Jones EY, Stuart DI, Screaton G, Ebner D, Hoosdally S, Chand M, Crook DW, O’Donnell A-M, Conlon CP, Pouwels KB, Walker AS, Peto TEA, Hopkins S, Walker TM, Jeffery K, Eyre DW, Oxford University Hospitals Staff Testing Group. Antibody Status and Incidence of SARS-CoV-2 Infection in Health Care Workers. N Engl J Med. 2021 Feb 11;384(6):533-540. doi: 10.1056/NEJMoa2034545. PMCID: PMC7781098 PMID: 33369366

6. Anderson EJ, Rouphael NG, Widge AT, Jackson LA, Roberts PC, Makhene M, Chappell JD, Denison MR, Stevens LJ, Pruijssers AJ, McDermott AB, Flach B, Lin BC, Doria-Rose NA, O’Dell S, Schmidt SD, Corbett KS, Swanson PA, Padilla M, Neuzil KM, Bennett H, Leav B, Makowski M, Albert J, Cross K, Edara VV, Floyd K, Suthar MS, Martinez DR, Baric R, Buchanan W, Luke CJ, Phadke VK, Rostad CA, Ledgerwood JE, Graham BS, Beigel JH, mRNA-1273 Study Group. Safety and Immunogenicity of SARS-CoV-2 mRNA-1273 Vaccine in Older Adults. N Engl J Med. 2020 Dec 17;383(25):2427-2438. doi: 10.1056/NEJMoa2028436. PMCID: PMC7556339 PMID: 32991794

7. Long Q-X, Liu B-Z, Deng H-J, Wu G-C, Deng K, Chen Y-K, Liao P, Qiu J-F, Lin Y, Cai X-F, Wang D-Q, Hu Y, Ren J-H, Tang N, Xu Y-Y, Yu L-H, Mo Z, Gong F, Zhang X-L, Tian W-G, Hu L, Zhang X-X, Xiang J-L, Du H-X, Liu H-W, Lang C-H, Luo X-H, Wu S-B, Cui X-P, Zhou Z, Zhu M-M, Wang J, Xue C-J, Li X-F, Wang L, Li Z-J, Wang K, Niu C-C, Yang Q-J, Tang X-J, Zhang Y, Liu X-M, Li J-J, Zhang D-C, Zhang F, Liu P, Yuan J, Li Q, Hu J-L, Chen J, Huang A-L. Antibody responses to SARSCoV-2 in patients with COVID-19. Nat Med. 2020 Jun;26(6):845-848. doi: 10.1038/ s41591-020-0897-1. PMID: 32350462

8. Bahadoran A, Lee SH, Wang SM, Manikam R, Rajarajeswaran J, Raju CS, Sekaran SD. Immune Responses to Influenza Virus and Its Correlation to Age and Inherited Factors. Front Microbiol [Internet]. 2016 Nov 22 [cited 2020 Dec 6];7. doi: 10.3389/ fmicb.2016.01841. Available from: https://www.ncbi.nlm.nih.gov/pmc/articles/ PMC5118461/ PMCID: PMC5118461 PMID: 27920759

9. Chaplin DD. Overview of the Immune Response. J Allergy Clin Immunol. 2010 Feb;125(2 Suppl 2):S3-23. doi: 10.1016/j.jaci.2009.12.980. PMCID: PMC2923430 PMID: 20176265

10. Krammer F. The human antibody response to influenza A virus infection and vaccination. Nat Rev Immunol. 2019 Jun;19(6):383-397. doi: 10.1038/s41577-019-0143-6. PMID: 30837674

11. Zhou D, Zhang Y, Li Q, Chen Y, He B, Yang J, Tu H, Lei L, Yan H. Matrix Protein-Specific IgA Antibody Inhibits Measles Virus Replication by Intracellular 
Neutralization. J Virol. 2011 Nov;85(21):11090-11097. doi: 10.1128/JVI.00768-11. PMCID: PMC3194966 PMID: 21865386

12. El Mubarak HS, Ibrahim SA, Vos HW, Mukhtar MM, Mustafa OA, Wild TF, Osterhaus ADME, de Swart RL. Measles virus protein-specific IgM, IgA, and IgG subclass responses during the acute and convalescent phase of infection. J Med Virol. 2004 Feb;72(2):290-298. doi: 10.1002/jmv.10553. PMID: 14695672

13. Huang AT, Garcia-Carreras B, Hitchings MDT, Yang B, Katzelnick LC, Rattigan SM, Borgert BA, Moreno CA, Solomon BD, Trimmer-Smith L, Etienne V, Rodriguez-Barraquer I, Lessler J, Salje H, Burke DS, Wesolowski A, Cummings DAT. A systematic review of antibody mediated immunity to coronaviruses: kinetics, correlates of protection, and association with severity. Nat Commun. 2020 17;11(1):4704. doi: 10.1038/s41467-020-18450-4. PMCID: PMC7499300 PMID: 32943637

14. Coughlin MM, Prabhakar BS. Neutralizing human monoclonal antibodies to severe acute respiratory syndrome coronavirus: target, mechanism of action, and therapeutic potential. Rev Med Virol. 2012 Jan;22(1):2-17. doi: 10.1002/rmv.706. PMCID: PMC3256278 PMID: 21905149

15. Russell CD, Unger SA, Walton M, Schwarze J. The Human Immune Response to Respiratory Syncytial Virus Infection. Clin Microbiol Rev. 2017 Apr;30(2):481-502. doi: 10.1128/CMR.00090-16. PMCID: PMC5355638 PMID: 28179378

16. Lee WS, Wheatley AK, Kent SJ, DeKosky BJ. Antibody-dependent enhancement and SARS-CoV-2 vaccines and therapies. Nat Microbiol. 2020 Oct;5(10):1185-1191. doi: 10.1038/s41564-020-00789-5. PMID: 32908214

17. Calabrese LH, Calabrese C, Lenfant T, Kirchner E, Strand V. Infections in the Era of Targeted Therapies: Mapping the Road Ahead. Front Med (Lausanne). 2020;7:336. doi: 10.3389/fmed.2020.00336. PMCID: PMC7461856 PMID: 32974356

18. Tricco AC, Lillie E, Zarin W, O’Brien KK, Colquhoun H, Levac D, Moher D, Peters MDJ, Horsley T, Weeks L, Hempel S, Akl EA, Chang C, McGowan J, Stewart L, Hartling L, Aldcroft A, Wilson MG, Garritty C, Lewin S, Godfrey CM, Macdonald MT, Langlois EV, Soares-Weiser K, Moriarty J, Clifford T, Tunçalp Ö, Straus SE. PRISMA Extension for Scoping Reviews (PRISMA-ScR): Checklist and Explanation. Ann Intern Med. 2018 Oct 2;169(7):467-473. doi: 10.7326/M18-0850. PMID: 30178033

19. Abraham RS, Marshall JM, Kuehn HS, Rueda CM, Gibbs A, Guider W, Stewart C, Rosenzweig SD, Wang H, Jean S, Peeples M, King T, Hunt WG, Honegger JR, Ramilo O, Mustillo PJ, Mejias A, Ardura MI, Shimamura M. Severe SARS-CoV-2 disease in the context of a NF- $\mathrm{B} 2$ loss-of-function pathogenic variant. J Allergy Clin Immunol. 2021 Feb;147(2):532-544.e1. doi: 10.1016/j.jaci.2020.09.020. PMCID: PMC7525247 PMID: 33007327

20. Pfeuffer S, Pawlowski M, Joos GS, Minnerup J, Meuth SG, Dziewas R, Wiendl H. Autoimmunity complicating SARS-CoV-2 infection in selective IgA-deficiency. Neurol Neuroimmunol Neuroinflamm [Internet]. 2020 Aug 12 [cited 2020 Nov 29];7(6). doi: 10.1212/NXI.0000000000000881. Available from: https://www.ncbi.nlm.nih.gov/ pmc/articles/PMC7428357/ PMCID: PMC7428357 PMID: 32817413 
21. Buckland MS, Galloway JB, Fhogartaigh CN, Meredith L, Provine NM, Bloor S, Ogbe A, Zelek WM, Smielewska A, Yakovleva A, Mann T, Bergamaschi L, Turner L, Mescia F, Toonen EJM, Hackstein C-P, Akther HD, Vieira VA, Ceron-Gutierrez L, Periselneris J, Kiani-Alikhan S, Grigoriadou S, Vaghela D, Lear SE, Török ME, Hamilton WL, Stockton J, Quick J, Nelson P, Hunter M, Coulter TI, Devlin L, CITIID-NIHR COVID-19 BioResource Collaboration, MRC-Toxicology Unit COVID-19 Consortium, Bradley JR, Smith KGC, Ouwehand WH, Estcourt L, Harvala H, Roberts DJ, Wilkinson IB, Screaton N, Loman N, Doffinger R, Lyons PA, Morgan BP, Goodfellow IG, Klenerman P, Lehner PJ, Matheson NJ, Thaventhiran JED. Treatment of COVID-19 with remdesivir in the absence of humoral immunity: a case report. Nat Commun. 2020 Dec 14;11(1):6385. doi: 10.1038/s41467-020-19761-2. PMID: 33318491

22. Mullur J, Wang A, Feldweg A. A fatal case of coronavirus disease 2019 in a patient with common variable immunodeficiency. Ann Allergy Asthma Immunol. 2021 Jan;126(1):90-92. doi: 10.1016/j.anai.2020.08.017. PMCID: PMC7431323 PMID: 32818593

23. Ribeiro LC, Benites BD, Ulaf RG, Nunes TA, Costa-Lima C, Addas-Carvalho M, Proenca-Modena JL, Granja F, da Costa VA, Duarte A da SS, Zangirolami AB, Amaro EC, Mansour E, Zollner RL, Velloso LA. Rapid clinical recovery of a SARS-CoV-2 infected common variable immunodeficiency patient following the infusion of COVID-19 convalescent plasma. Allergy Asthma Clin Immunol. 2021 Feb 5;17(1):14. doi: 10.1186/s13223-021-00518-5. PMCID: PMC7862981 PMID: 33546745

24. Ahanchian H, Moazzen N, Sezavar M, Khalighi N, Khoshkhui M, Aelami MH, Motevalli Haghi NS, Rezaei N. COVID-19 in a child with primary antibody deficiency. Clin Case Rep. 2021 Feb;9(2):755-758. doi: 10.1002/ccr3.3643. PMCID: PMC7869323 PMID: 33598240

25. Ho H-E, Mathew S, Peluso MJ, Cunningham-Rundles C. Clinical outcomes and features of COVID-19 in patients with primary immunodeficiencies in New York City. J Allergy Clin Immunol Pract. 2020 Oct 8; doi: 10.1016/j.jaip.2020.09.052. PMCID: PMC7543763 PMID: 33039649

26. Meyts I, Bucciol G, Quinti I, Neven B, Fischer A, Seoane E, Lopez-Granados E, Gianelli C, Robles-Marhuenda A, Jeandel P-Y, Paillard C, Sankaran VG, Demirdag YY, Lougaris V, Aiuti A, Plebani A, Milito C, Dalm VA, Guevara-Hoyer K, Sánchez-Ramón S, Bezrodnik L, Barzaghi F, Gonzalez-Granado LI, Hayman GR, Uzel G, Mendonça LO, Agostini C, Spadaro G, Badolato R, Soresina A, Vermeulen F, Bosteels C, Lambrecht BN, Keller M, Mustillo PJ, Abraham RS, Gupta S, Ozen A, Karakoc-Aydiner E, Baris S, Freeman AF, Yamazaki-Nakashimada M, Scheffler-Mendoza S, Espinosa-Padilla S, Gennery AR, Jolles S, Espinosa Y, Poli MC, Fieschi C, Hauck F, Cunningham-Rundles C, Mahlaoui N, Warnatz K, Sullivan KE, Tangye SG. Coronavirus disease 2019 in patients with inborn errors of immunity: An international study. Journal of Allergy and Clinical Immunology [Internet]. Elsevier; 2020 Sep 24 [cited 2020 Dec 6];0(0). doi: 10.1016/j.jaci.2020.09.010. Available from: https://www. 
jacionline.org/article/S0091-6749(20)31320-8/abstract PMID: 32980424

27. Delavari S, Abolhassani H, Abolnezhadian F, Babaha F, Iranparast S, Ahanchian H, Moazzen N, Nabavi M, Arshi S, Fallahpour M, Bemanian MH, Shokri S, Momen T, Sadeghi-Shabestari M, Molatefi R, Shirkani A, Vosughimotlagh A, Safarirad M, Sharifzadeh M, Pashangzadeh S, Salami F, Shirmast P, Rezaei A, Moeini Shad T, Mohraz M, Rezaei N, Hammarström L, Yazdani R, Aghamohamamdi A. Impact of SARS-CoV-2 Pandemic on Patients with Primary Immunodeficiency. J Clin Immunol. 2020 Dec 1; doi: 10.1007/s10875-020-00928-x. PMCID: PMC7707812 PMID: 33263173

28. Marcus N, Frizinsky S, Hagin D, Ovadia A, Hanna S, Farkash M, Maoz-Segal R, Agmon-Levin N, Broides A, Nahum A, Rosenberg E, Kuperman AA, Dinur-Schejter Y, Berkun Y, Toker O, Goldberg S, Confino-Cohen R, Scheuerman O, Badarneh B, Epstein-Rigbi N, Etzioni A, Dalal I, Somech R. Minor Clinical Impact of COVID-19 Pandemic on Patients With Primary Immunodeficiency in Israel. Front Immunol. 2020;11:614086. doi: 10.3389/fimmu.2020.614086. PMCID: PMC7840610 PMID: 33519822

29. Corse T, Dayan L, Kersten S, Battaglia F, Terlecky SR, Han Z. Clinical Outcomes of COVID-19 Patients with Pre-existing, Compromised Immune Systems: A Review of Case Reports. Int J Med Sci. 2020;17(18):2974-2986. doi: 10.7150/ijms.50537. PMCID: PMC7646123 PMID: 33173418

30. Safavi F, Nourbakhsh B, Azimi AR. B-cell depleting therapies may affect susceptibility to acute respiratory illness among patients with multiple sclerosis during the early COVID-19 epidemic in Iran. Mult Scler Relat Disord. 2020 Aug;43:102195. doi: 10.1016/j.msard.2020.102195. PMCID: PMC7219389 PMID: 32460086

31. Sahraian MA, Azimi A, Navardi S, Ala S, Naser Moghadasi A. Evaluation of the rate of COVID-19 infection, hospitalization and death among Iranian patients with multiple sclerosis. Mult Scler Relat Disord. 2020 Nov;46:102472. doi: 10.1016/j. msard.2020.102472. PMCID: PMC7456295 PMID: 32890817

32. Sormani MP, De Rossi N, Schiavetti I, Carmisciano L, Cordioli C, Moiola L, Radaelli M, Immovilli P, Capobianco M, Trojano M, Zaratin P, Tedeschi G, Comi G, Battaglia MA, Patti F, Salvetti M, Musc-19 Study Group. Disease-Modifying Therapies and Coronavirus Disease 2019 Severity in Multiple Sclerosis. Ann Neurol. 2021 Apr;89(4):780-789. doi: 10.1002/ana.26028. PMCID: PMC8013440 PMID: 33480077

33. Parrotta E, Kister I, Charvet L, Sammarco C, Saha V, Charlson RE, Howard J, Gutman JM, Gottesman M, Abou-Fayssal N, Wolintz R, Keilson M, Fernandez-Carbonell C, Krupp LB, Zhovtis Ryerson L. COVID-19 outcomes in MS: Observational study of early experience from NYU Multiple Sclerosis Comprehensive Care Center. Neurol Neuroimmunol Neuroinflamm. 2020 Sep;7(5). doi: 10.1212/ NXI.0000000000000835. PMCID: PMC7357412 PMID: 32646885

34. Contributors F/SFR/SNFMI/SOFREMIP/CRI/IMIDIATE consortium and contributors. Severity of COVID-19 and survival in patients with rheumatic and inflammatory diseases: data from the French RMD COVID-19 cohort of 694 patients. Annals 
of the Rheumatic Diseases [Internet]. BMJ Publishing Group Ltd; 2020 Dec 2 [cited 2021 Jan 13]; doi: 10.1136/annrheumdis-2020-218310. Available from: https://ard. bmj.com/content/early/2020/12/01/annrheumdis-2020-218310 PMID: 33268442

35. Avouac J, Drumez E, Hachulla E, Seror R, Georgin-Lavialle S, El Mahou S, Pertuiset E, Pham T, Marotte H, Servettaz A, Domont F, Chazerain P, Devaux M, Claudepierre P, Langlois V, Mekinian A, Maria ATJ, Banneville B, Fautrel B, Pouchot J, Thomas T, Flipo R-M, Richez C, FAI2R/SFR/SNFMI/SOFREMIP/CRI/IMIDIATE consortium and contributors. COVID-19 outcomes in patients with inflammatory rheumatic and musculoskeletal diseases treated with rituximab: a cohort study. Lancet Rheumatol. 2021 Mar 25; doi: 10.1016/S2665-9913(21)00059-X. PMCID: PMC7993930 PMID: 33786454

36. Salter A, Fox RJ, Newsome SD, Halper J, Li DKB, Kanellis P, Costello K, Bebo B, Rammohan K, Cutter GR, Cross AH. Outcomes and Risk Factors Associated With SARS-CoV-2 Infection in a North American Registry of Patients With Multiple Sclerosis. JAMA Neurol. 2021 Mar 19; doi: 10.1001/jamaneurol.2021.0688. PMCID: PMC7980147 PMID: 33739362

37. Strangfeld A, Schäfer M, Gianfrancesco MA, Lawson-Tovey S, Liew JW, Ljung L, Mateus EF, Richez C, Santos MJ, Schmajuk G, Scirè CA, Sirotich E, Sparks JA, Sufka P, Thomas T, Trupin L, Wallace ZS, Al-Adely S, Bachiller-Corral J, Bhana S, Cacoub P, Carmona L, Costello R, Costello W, Gossec L, Grainger R, Hachulla E, Hasseli R, Hausmann JS, Hyrich KL, Izadi Z, Jacobsohn L, Katz P, Kearsley-Fleet L, Robinson PC, Yazdany J, Machado PM, COVID-19 Global Rheumatology Alliance. Factors associated with COVID-19-related death in people with rheumatic diseases: results from the COVID-19 Global Rheumatology Alliance physician-reported registry. Ann Rheum Dis. 2021 Jan 27; doi: 10.1136/annrheumdis-2020-219498. PMCID: PMC7843211 PMID: 33504483

38. Hueso T, Pouderoux C, Péré H, Beaumont A-L, Raillon L-A, Ader F, Chatenoud L, Eshagh D, Szwebel T-A, Martinot M, Camou F, Crickx E, Michel M, Mahevas M, Boutboul D, Azoulay E, Joseph A, Hermine O, Rouzaud C, Faguer S, Petua P, Pommeret F, Clerc S, Planquette B, Merabet F, London J, Zeller V, Ghez D, Veyer D, Ouedrani A, Gallian P, Pacanowski J, Mékinian A, Garnier M, Pirenne F, Tiberghien P, Lacombe K. Convalescent plasma therapy for B-cell-depleted patients with protracted COVID-19. Blood. United States; 2020 Nov 12;136(20):2290-2295. doi: 10.1182/ blood.2020008423. PMID: 32959052

39. McMahan K, Yu J, Mercado NB, Loos C, Tostanoski LH, Chandrashekar A, Liu J, Peter L, Atyeo C, Zhu A, Bondzie EA, Dagotto G, Gebre MS, Jacob-Dolan C, Li Z, Nampanya F, Patel S, Pessaint L, Van Ry A, Blade K, Yalley-Ogunro J, Cabus M, Brown R, Cook A, Teow E, Andersen H, Lewis MG, Lauffenburger DA, Alter G, Barouch DH. Correlates of protection against SARS-CoV-2 in rhesus macaques. Nature. 2021 Feb;590(7847):630-634. doi: 10.1038/s41586-020-03041-6. PMCID: PMC7906955 PMID: 33276369

40. Corbett KS, Flynn B, Foulds KE, Francica JR, Boyoglu-Barnum S, Werner AP, Flach B, O’Connell S, Bock KW, Minai M, Nagata BM, Andersen H, Martinez DR, Noe AT, 
Douek N, Donaldson MM, Nji NN, Alvarado GS, Edwards DK, Flebbe DR, Lamb E, Doria-Rose NA, Lin BC, Louder MK, O’Dell S, Schmidt SD, Phung E, Chang LA, Yap C, Todd J-PM, Pessaint L, Ry AV, Browne S, Greenhouse J, Putman-Taylor T, Strasbaugh A, Campbell T-A, Cook A, Dodson A, Steingrebe K, Shi W, Zhang Y, Abiona OM, Wang L, Pegu A, Yang ES, Leung K, Zhou T, Teng I-T, Widge A, Gordon I, Novik L, Gillespie RA, Loomis RJ, Moliva JI, Stewart-Jones G, Himansu S, Kong W-P, Nason MC, Morabito KM, Ruckwardt TJ, Ledgerwood JE, Gaudinski MR, Kwong PD, Mascola JR, Carfi A, Lewis MG, Baric RS, McDermott A, Moore IN, Sullivan NJ, Roederer M, Seder RA, Graham BS. Evaluation of the mRNA-1273 Vaccine against SARS-CoV-2 in Nonhuman Primates. New England Journal of Medicine [Internet]. Massachusetts Medical Society; 2020 Jul 28 [cited 2021 Feb 5]; doi: 10.1056/NEJMoa2024671. Available from: https://www.nejm.org/doi/10.1056/ NEJMoa2024671

41. Weinreich DM, Sivapalasingam S, Norton T, Ali S, Gao H, Bhore R, Musser BJ, Soo Y, Rofail D, Im J, Perry C, Pan C, Hosain R, Mahmood A, Davis JD, Turner KC, Hooper AT, Hamilton JD, Baum A, Kyratsous CA, Kim Y, Cook A, Kampman W, Kohli A, Sachdeva Y, Graber X, Kowal B, DiCioccio T, Stahl N, Lipsich L, Braunstein N, Herman G, Yancopoulos GD, Trial Investigators. REGN-COV2, a Neutralizing Antibody Cocktail, in Outpatients with Covid-19. N Engl J Med. 2021 Jan 21;384(3):238-251. doi: 10.1056/NEJMoa2035002. PMCID: PMC7781102 PMID: 33332778

42. Abolghasemi H, Eshghi P, Cheraghali AM, Imani Fooladi AA, Bolouki Moghaddam F, Imanizadeh S, Moeini Maleki M, Ranjkesh M, Rezapour M, Bahramifar A, Einollahi B, Hosseini MJ, Jafari NJ, Nikpouraghdam M, Sadri N, Tazik M, Sali S, Okati S, Askari E, Tabarsi P, Aslani J, Sharifipour E, Jarahzadeh MH, Khodakarim N, Salesi M, Jafari R, Shahverdi S. Clinical efficacy of convalescent plasma for treatment of COVID-19 infections: Results of a multicenter clinical study. Transfus Apher Sci. 2020 Oct;59(5):102875. doi: 10.1016/j.transci.2020.102875. PMCID: PMC7362821 PMID: 32694043

43. Piccoli L, Park Y-J, Tortorici MA, Czudnochowski N, Walls AC, Beltramello M, Silacci-Fregni C, Pinto D, Rosen LE, Bowen JE, Acton OJ, Jaconi S, Guarino B, Minola A, Zatta F, Sprugasci N, Bassi J, Peter A, De Marco A, Nix JC, Mele F, Jovic S, Rodriguez BF, Gupta SV, Jin F, Piumatti G, Lo Presti G, Pellanda AF, Biggiogero M, Tarkowski M, Pizzuto MS, Cameroni E, Havenar-Daughton C, Smithey M, Hong D, Lepori V, Albanese E, Ceschi A, Bernasconi E, Elzi L, Ferrari P, Garzoni C, Riva A, Snell G, Sallusto F, Fink K, Virgin HW, Lanzavecchia A, Corti D, Veesler D. Mapping Neutralizing and Immunodominant Sites on the SARS-CoV-2 Spike Receptor-Binding Domain by Structure-Guided High-Resolution Serology. Cell. 2020 Nov 12;183(4):1024-1042.e21. doi: 10.1016/j.cell.2020.09.037. PMCID: PMC7494283 PMID: 32991844

44. Robbiani DF, Gaebler C, Muecksch F, Lorenzi JCC, Wang Z, Cho A, Agudelo M, Barnes CO, Gazumyan A, Finkin S, Hägglöf T, Oliveira TY, Viant C, Hurley A, Hoffmann H-H, Millard KG, Kost RG, Cipolla M, Gordon K, Bianchini F, Chen ST, Ramos V, Patel R, Dizon J, Shimeliovich I, Mendoza P, Hartweger H, Nogueira 
L, Pack M, Horowitz J, Schmidt F, Weisblum Y, Michailidis E, Ashbrook AW, Waltari E, Pak JE, Huey-Tubman KE, Koranda N, Hoffman PR, West AP, Rice CM, Hatziioannou T, Bjorkman PJ, Bieniasz PD, Caskey M, Nussenzweig MC. Convergent antibody responses to SARS-CoV-2 in convalescent individuals. Nature. 2020 Aug;584(7821):437-442. doi: 10.1038/s41586-020-2456-9. PMCID: PMC7442695 PMID: 32555388

45. Sette A, Crotty S. Adaptive immunity to SARS-CoV-2 and COVID-19. Cell. 2021 Feb 18;184(4):861-880. doi: 10.1016/j.cell.2021.01.007. PMCID: PMC7803150 PMID: 33497610

46. Gudbjartsson DF, Norddahl GL, Melsted P, Gunnarsdottir K, Holm H, Eythorsson E, Arnthorsson AO, Helgason D, Bjarnadottir K, Ingvarsson RF, Thorsteinsdottir B, Kristjansdottir S, Birgisdottir K, Kristinsdottir AM, Sigurdsson MI, Arnadottir GA, Ivarsdottir EV, Andresdottir M, Jonsson F, Agustsdottir AB, Berglund J, Eiriksdottir B, Fridriksdottir R, Gardarsdottir EE, Gottfredsson M, Gretarsdottir OS, Gudmundsdottir S, Gudmundsson KR, Gunnarsdottir TR, Gylfason A, Helgason A, Jensson BO, Jonasdottir A, Jonsson H, Kristjansson T, Kristinsson KG, Magnusdottir DN, Magnusson OT, Olafsdottir LB, Rognvaldsson S, le Roux L, Sigmundsdottir G, Sigurdsson A, Sveinbjornsson G, Sveinsdottir KE, Sveinsdottir M, Thorarensen EA, Thorbjornsson B, Thordardottir M, Saemundsdottir J, Kristjansson SH, Josefsdottir KS, Masson G, Georgsson G, Kristjansson M, Moller A, Palsson R, Gudnason T, Thorsteinsdottir U, Jonsdottir I, Sulem P, Stefansson K. Humoral Immune Response to SARS-CoV-2 in Iceland. N Engl J Med. 2020 Oct 29;383(18):1724-1734. doi: 10.1056/NEJMoa2026116. PMCID: PMC7494247 PMID: 32871063

47. Shields AM, Burns SO, Savic S, Richter AG, UK PIN COVID-19 Consortium. COVID-19 in patients with primary and secondary immunodeficiency: The United Kingdom experience. J Allergy Clin Immunol. 2020 Dec 15; doi: 10.1016/j. jaci.2020.12.620. PMCID: PMC7737531 PMID: 33338534

48. Ahn S, Cunningham-Rundles C. Role of B cells in common variable immune deficiency. Expert Rev Clin Immunol. 2009 Sep;5(5):557-564. doi: 10.1586/eci.09.43. PMCID: PMC2922984 PMID: 20477641

49. Wong GK, Huissoon AP. T-cell abnormalities in common variable immunodeficiency: the hidden defect. J Clin Pathol. 2016 Aug;69(8):672-676. doi: 10.1136/jclinpath-2015-203351. PMCID: PMC4975840 PMID: 27153873

50. Liu Y, Wu Y, Lam K-T, Lee PP-W, Tu W, Lau Y-L. Dendritic and T cell response to influenza is normal in the patients with $\mathrm{X}$-linked agammaglobulinemia. J Clin Immunol. 2012 Jun;32(3):421-429. doi: 10.1007/s10875-011-9639-y. PMCID: PMC3350625 PMID: 22289994

51. Quinti I, Soresina A, Spadaro G, Martino S, Donnanno S, Agostini C, Claudio P, Franco D, Maria Pesce A, Borghese F, Guerra A, Rondelli R, Plebani A, Italian Primary Immunodeficiency Network. Long-term follow-up and outcome of a large cohort of patients with common variable immunodeficiency. J Clin Immunol. 2007 May;27(3):308-316. doi: 10.1007/s10875-007-9075-1. PMID: 17510807 
52. Ardeniz O, Cunningham-Rundles C. Granulomatous disease in common variable immunodeficiency. Clin Immunol. 2009 Nov;133(2):198-207. doi: 10.1016/j. clim.2009.05.001. PMCID: PMC2760682 PMID: 19716342

53. Verbsky JW, Routes JM. Sarcoidosis and common variable immunodeficiency: similarities and differences. Semin Respir Crit Care Med. 2014 Jun;35(3):330-335. doi: 10.1055/s-0034-1376862. PMID: 25007085

54. Ho H-E, Cunningham-Rundles C. Non-infectious Complications of Common Variable Immunodeficiency: Updated Clinical Spectrum, Sequelae, and Insights to Pathogenesis. Front Immunol. 2020;11:149. doi: 10.3389/fimmu.2020.00149. PMCID: PMC7025475 PMID: 32117289

55. Fernando SL, Jang HS-I, Li J. The Immune Dysregulation of Common Variable Immunodeficiency Disorders. Immunol Lett. 2021 Feb;230:21-26. doi: 10.1016/j. imlet.2020.12.002. PMID: 33333111

56. Page TH, Urbaniak AM, Espirito Santo AI, Danks L, Smallie T, Williams LM, Horwood NJ. Bruton's tyrosine kinase regulates TLR7/8-induced TNF transcription via nuclear factor- $\mathrm{KB}$ recruitment. Biochem Biophys Res Commun. 2018 May 5;499(2):260-266. doi: 10.1016/j.bbrc.2018.03.140. PMCID: PMC5887515 PMID: 29567473

57. Roschewski M, Lionakis MS, Sharman JP, Roswarski J, Goy A, Monticelli MA, Roshon M, Wrzesinski SH, Desai JV, Zarakas MA, Collen J, Rose KM, Hamdy A, Izumi R, Wright GW, Chung KK, Baselga J, Staudt LM, Wilson WH. Inhibition of Bruton tyrosine kinase in patients with severe COVID-19. Science Immunology [Internet]. Science Immunology; 2020 Jun 5 [cited 2020 Oct 11];5(48). doi: 10.1126/sciimmunol.abd0110. Available from: https://immunology.sciencemag.org/content/5/48/ eabd0110 PMID: 32503877

58. Gupta S, Su H, Narsai T, Agrawal S. SARS-CoV-2-Associated T-Cell Responses in the Presence of Humoral Immunodeficiency. IAA. Karger Publishers; 2021;182(3):195209. doi: 10.1159/000514193. PMID: 33486489

59. van Vollenhoven RF, Emery P, Bingham CO, Keystone EC, Fleischmann R, Furst DE, Macey K, Sweetser M, Kelman A, Rao R. Longterm safety of patients receiving rituximab in rheumatoid arthritis clinical trials. J Rheumatol. 2010 Mar;37(3):558-567. doi: 10.3899/jrheum.090856. PMID: 20110520

60. Gottenberg J-E, Ravaud P, Bardin T, Cacoub P, Cantagrel A, Combe B, Dougados M, Flipo RM, Godeau B, Guillevin L, Le Loët X, Hachulla E, Schaeverbeke T, Sibilia J, Baron G, Mariette X, AutoImmunity and Rituximab registry and French Society of Rheumatology. Risk factors for severe infections in patients with rheumatoid arthritis treated with rituximab in the autoimmunity and rituximab registry. Arthritis Rheum. 2010 Sep;62(9):2625-2632. doi: 10.1002/art.27555. PMID: 20506353

61. Caporali R, Caprioli M, Bobbio-Pallavicini F, Bugatti S, Montecucco C. Long term treatment of rheumatoid arthritis with rituximab. Autoimmun Rev. 2009 Jun;8(7):591-594. doi: 10.1016/j.autrev.2009.02.008. PMID: 19393205

62. Luna G, Alping P, Burman J, Fink K, Fogdell-Hahn A, Gunnarsson M, Hillert J, 
Langer-Gould A, Lycke J, Nilsson P, Salzer J, Svenningsson A, Vrethem M, Olsson T, Piehl F, Frisell T. Infection Risks Among Patients With Multiple Sclerosis Treated With Fingolimod, Natalizumab, Rituximab, and Injectable Therapies. JAMA Neurol. 2020 Feb 1;77(2):184-191. doi: 10.1001/jamaneurol.2019.3365. PMCID: PMC6784753 PMID: 31589278

63. Hughes R, Whitley L, Fitovski K, Schneble H-M, Muros E, Sauter A, Craveiro L, Dillon P, Bonati U, Jessop N, Pedotti R, Koendgen H. COVID-19 in ocrelizumab-treated people with multiple sclerosis. Mult Scler Relat Disord. 2021 Apr;49:102725. doi: 10.1016/j.msard.2020.102725. PMCID: PMC7772086 PMID: 33482590

64. Bingham CO, Looney RJ, Deodhar A, Halsey N, Greenwald M, Codding C, Trzaskoma B, Martin F, Agarwal S, Kelman A. Immunization responses in rheumatoid arthritis patients treated with rituximab: results from a controlled clinical trial. Arthritis Rheum. 2010 Jan;62(1):64-74. doi: 10.1002/art.25034. PMID: 20039397

65. Ciotti JR, Valtcheva MV, Cross AH. Effects of MS disease-modifying therapies on responses to vaccinations: A review. Mult Scler Relat Disord. 2020 Oct;45:102439. doi: 10.1016/j.msard.2020.102439. PMCID: PMC7395588 PMID: 32769063

66. Papp KA, Haraoui B, Kumar D, Marshall JK, Bissonnette R, Bitton A, Bressler B, Gooderham M, Ho V, Jamal S, Pope JE, Steinhart AH, Vinh DC, Wade J. Vaccination Guidelines for Patients With Immune-Mediated Disorders on Immunosuppressive Therapies. J Cutan Med Surg. 2019 Jan;23(1):50-74. doi: 10.1177/1203475418811335. PMCID: PMC6330697 PMID: 30463418

67. Zhang J, Xie F, Delzell E, Chen L, Winthrop K, Lewis JD, Saag K, Baddley JW, Curtis JR. Association between Vaccination for Herpes Zoster and Risk of Herpes Zoster Infection among Older Patients with Selected Immune-mediated Diseases. JAMA. 2012 Jul 4;308(1):43-49. doi: 10.1001/jama.2012.7304. PMCID: PMC3683869 PMID: 22760290

68. Tesoriero JM, Swain C-AE, Pierce JL, Zamboni L, Wu M, Holtgrave DR, Gonzalez CJ, Udo T, Morne JE, Hart-Malloy R, Rajulu DT, Leung S-YJ, Rosenberg ES. COVID-19 Outcomes Among Persons Living With or Without Diagnosed HIV Infection in New York State. JAMA Netw Open. 2021 Feb 1;4(2):e2037069. doi: 10.1001/jamanetworkopen.2020.37069. PMCID: PMC7859843 PMID: 33533933

69. Moir S, Fauci AS. B cells in HIV infection and disease. Nat Rev Immunol. 2009 Apr;9(4):235-245. doi: 10.1038/nri2524. PMCID: PMC2779527 PMID: 19319142

70. Houot R, Levy R, Cartron G, Armand P. Could anti-CD20 therapy jeopardise the efficacy of a SARS-CoV-2 vaccine? Eur J Cancer. 2020 Sep;136:4-6. doi: 10.1016/j. ejca.2020.06.017. PMCID: PMC7315961 PMID: 32619884

71. Baker D, Roberts CAK, Pryce G, Kang AS, Marta M, Reyes S, Schmierer K, Giovannoni G, Amor S. COVID-19 vaccine-readiness for anti-CD20-depleting therapy in autoimmune diseases. Clin Exp Immunol. 2020 Nov;202(2):149-161. doi: 10.1111/ cei.13495. PMCID: PMC7405500 PMID: 32671831

72. Gardulf A, Abolhassani H, Gustafson R, Eriksson LE, Hammarström L. Predictive markers for humoral influenza vaccine response in patients with common variable 
immunodeficiency. J Allergy Clin Immunol. 2018 Dec;142(6):1922-1931.e2. doi: 10.1016/j.jaci.2018.02.052. PMID: 29678747

73. Montero-Escribano P, Matías-Guiu J, Gómez-Iglesias P, Porta-Etessam J, Pytel V, Matias-Guiu JA. Anti-CD20 and COVID-19 in multiple sclerosis and related disorders: A case series of 60 patients from Madrid, Spain. Mult Scler Relat Disord. 2020 Jul;42:102185. doi: 10.1016/j.msard.2020.102185. PMCID: PMC7204643 PMID: 32408147

74. Guevara C, Villa E, Rosas CS, Diaz V, Naves R. Treating patients with multiple sclerosis during the COVID-19 pandemic: Assessing the expert recommendations. Mult Scler Relat Disord. 2020 Aug;43:102224. doi: 10.1016/j.msard.2020.102224. PMCID: PMC7245233 PMID: 32464582

75. Angeletti A, Drovandi S, Sanguineri F, Santaniello M, Ferrando G, Forno R, Cipresso G, Caridi G, Riella LV, Cravedi P, Ghiggeri GM. COVID-19 in Children with Nephrotic Syndrome on Anti-CD20 Chronic Immunosuppression. Clin J Am Soc Nephrol. 2020 Oct 7;15(10):1494-1495. doi: 10.2215/CJN.06400420. PMCID: PMC7536764 PMID: 32718953

76. Loarce-Martos J, García-Fernández A, López-Gutiérrez F, García-García V, Calvo-Sanz L, Del Bosque-Granero I, Terán-Tinedo MA, Boteanu A, Bachiller-Corral J, Vázquez-Díaz M. High rates of severe disease and death due to SARS-CoV-2 infection in rheumatic disease patients treated with rituximab: a descriptive study. Rheumatol Int. 2020 Dec;40(12):2015-2021. doi: 10.1007/s00296-020-04699-x. PMCID: PMC7499013 PMID: 32945944

77. Sanchez-Piedra C, Diaz-Torne C, Manero J, Pego-Reigosa JM, Rúa-Figueroa Í, Gonzalez-Gay MA, Gomez-Reino J, Alvaro-Gracia JM. Clinical features and outcomes of COVID-19 in patients with rheumatic diseases treated with biological and synthetic targeted therapies. Ann Rheum Dis. 2020 Jul;79(7):988-990. doi: 10.1136/ annrheumdis-2020-217948. PMCID: PMC7307213 PMID: 32503857

78. Nuño L, Navarro MN, Bonilla G, Franco-Gómez K, Aguado P, Peiteado D, Monjo I, Tornero C, Villalba A, Miranda-Carus M-E, Miguel ED, Bogas P, Castilla-Plaza A, Bernad-Pineda M, García-Lorenzo E, Rodríguez-Araya T, Balsa A. Clinical course, severity and mortality in a cohort of patients with COVID-19 with rheumatic diseases. Annals of the Rheumatic Diseases. BMJ Publishing Group Ltd; 2020 Dec 1;79(12):1659-1661. doi: 10.1136/annrheumdis-2020-218054. PMID: 32606046

79. Assaad S, Avrillon V, Fournier M-L, Mastroianni B, Russias B, Swalduz A, Cassier P, Eberst L, Steineur M-P, Kazes M, Perol M, Michallet A-S, Rey P, Erena-Penet A-S, Morel A, Brahmi M, Dufresne A, Tredan O, Chvetzoff G, Fayette J, de la Fouchardiere C, Ray-Coquard I, Bachelot T, Saintigny P, Tabutin M, Dupré A, Nicolas-Virelizier E, Belhabri A, Roux P-E, Fuhrmann C, Pilleul F, Basle A, Bouhamama A, Galvez C, Herr A-L, Gautier J, Chabaud S, Zrounba P, Perol D, Blay J-Y. High mortality rate in cancer patients with symptoms of COVID-19 with or without detectable SARS-COV-2 on RT-PCR. Eur J Cancer. 2020 Aug;135:251-259. doi: 10.1016/j. ejca.2020.05.028. PMCID: PMC7275994 PMID: 32540204 
80. Li Q, Zhu F, Xiao Y, Liu T, Liu X, Wu G, Zhang L. A Primary Mediastinal Large B-Cell Lymphoma Patient With COVID-19 Infection After Intensive Immunochemotherapy: A Case Report. Front Oncol. 2020;10:924. doi: 10.3389/fonc.2020.00924. PMCID: PMC7256193 PMID: 32574278

81. Lancman G, Mascarenhas J, Bar-Natan M. Severe COVID-19 virus reactivation following treatment for B cell acute lymphoblastic leukemia. J Hematol Oncol. 2020 Oct 2;13(1):131. doi: 10.1186/s13045-020-00968-1. PMCID: PMC7531062 PMID: 33008453

82. Tepasse P-R, Hafezi W, Lutz M, Kühn J, Wilms C, Wiewrodt R, Sackarnd J, Keller M, Schmidt HH, Vollenberg R. Persisting SARS-CoV-2 viraemia after rituximab therapy: two cases with fatal outcome and a review of the literature. $\mathrm{Br}$ J Haematol. 2020 Jul;190(2):185-188. doi: 10.1111/bjh.16896. PMCID: PMC7300950 PMID: 32557623

83. Clark E, Guilpain P, Filip IL, Pansu N, Le Bihan C, Cartron G, Tchernonog E, Roubille C, Morquin D, Makinson A, Tuaillon E, Le Moing V. Convalescent plasma for persisting COVID-19 following therapeutic lymphocyte depletion: a report of rapid recovery. Br J Haematol. 2020 Aug;190(3):e154-e156. doi: 10.1111/bjh.16981. PMCID: PMC7361823 PMID: 32593180

84. Yasuda H, Tsukune Y, Watanabe N, Sugimoto K, Uchimura A, Tateyama M, Miyashita Y, Ochi Y, Komatsu N. Persistent COVID-19 Pneumonia and Failure to Develop Anti-SARS-CoV-2 Antibodies During Rituximab Maintenance Therapy for Follicular Lymphoma. Clinical Lymphoma, Myeloma and Leukemia [Internet]. Elsevier; 2020 Aug 21 [cited 2020 Oct 18];0(0). doi: 10.1016/j.clml.2020.08.017. Available from: https://www.clinical-lymphoma-myeloma-leukemia.com/article/S21522650(20)30435-3/abstract PMID: 32933879

85. Martinot M, Jary A, Fafi-Kremer S, Leducq V, Delagreverie H, Garnier M, Pacanowski J, Mékinian A, Pirenne F, Tiberghien P, Calvez V, Humbrecht C, Marcelin A-G, Lacombe K. Remdesivir failure with SARS-CoV-2 RNA-dependent RNA-polymerase mutation in a B-cell immunodeficient patient with protracted Covid-19. Clin Infect Dis. 2020 Sep 28; doi: 10.1093/cid/ciaa1474. PMCID: PMC7543308 PMID: 32986807

86. Kos I, Balensiefer B, Roth S, Ahlgrimm M, Sester M, Schmidt T, Thurner L, Bewarder M, Bals R, Lammert F, Stilgenbauer S, Kaddu-Mulindwa D. Prolonged Course of COVID-19-Associated Pneumonia in a B-Cell Depleted Patient After Rituximab. Front Oncol. 2020;10:1578. doi: 10.3389/fonc.2020.01578. PMCID: PMC7493633 PMID: 32984017

87. Moore JL, Ganapathiraju PV, Kurtz CP, Wainscoat B. A 63-Year-Old Woman with a History of Non-Hodgkin Lymphoma with Persistent SARS-CoV-2 Infection Who Was Seronegative and Treated with Convalescent Plasma. Am J Case Rep. 2020 Oct 3;21:e927812. doi: 10.12659/AJCR.927812. PMCID: PMC7542548 PMID: 33009361

88. Malsy J, Veletzky L, Heide J, Hennigs A, Gil-Ibanez I, Stein A, Lütgehetmann M, Rosien U, Jasper D, Peine S, Hiller J, Haag F, Schmiedel S, Huber S, Jordan S, Addo MM, Schulze Zur Wiesch J. Sustained response after remdesivir and convalescent plasma therapy in a B-cell depleted patient with protracted COVID-19. Clin In- 
fect Dis. 2020 Oct 26; doi: 10.1093/cid/ciaa1637. PMCID: PMC7665388 PMID: 33103195

89. Elcioglu OC, Artan AS, Mirioglu S, Gursu M, Durdu B, Meric Koc M, Okyaltirik F, Gultekin MA, Kazancioglu R. COVİ-19 infection in a membranous nephropathy patient treated with rituximab. CEN Case Rep. 2020 Sep 4;1-5. doi: 10.1007/s13730020-00524-3. PMCID: PMC7472945 PMID: 32888168

90. Marinaki S, Tsiakas S, Skalioti C, Lourida P, Argyraki A, Grigorakos K, Boletis I. A Patient with Cryoglobulinemic Membranoproliferative GN (MPGN) Who Survived COVID-19 Disease: Case Presentation and Current Data of COVID-19 Infection in Dialysis and Transplanted Patients in Greece. Medicina (Kaunas). 2020 Jul 17;56(7). doi: 10.3390/medicina56070355. PMCID: PMC7404464 PMID: 32708858

91. Koff AG, Laurent-Rolle M, Hsu JC-C, Malinis M. Prolonged incubation of severe acute respiratory syndrome coronavirus 2 (SARS-CoV-2) in a patient on rituximab therapy. Infect Control Hosp Epidemiol. 2020 Oct 7;1-2. doi: 10.1017/ice.2020.1239. PMCID: PMC7578652 PMID: 33023685

92. Hakroush S, Franz J, Larsen J, Korsten P, Winkler MS, Tampe B. Repeated false-negative tests delayed diagnosis of COVID-19 in a case with granulomatosis with polyangiitis under maintenance therapy with rituximab and concomitant influenza pneumonia. Ann Rheum Dis. England; 2020 Jul 15; doi: 10.1136/annrheumdis-2020-218491. PMID: 32669300

93. Guilpain P, Le Bihan C, Foulongne V, Taourel P, Pansu N, Maria ATJ, Jung B, Larcher $\mathrm{R}$, Klouche K, Le Moing V. Rituximab for granulomatosis with polyangiitis in the pandemic of covid-19: lessons from a case with severe pneumonia. Ann Rheum Dis. 2020 Apr 20; doi: 10.1136/annrheumdis-2020-217549. PMID: 32312768

94. Leipe J, Wilke EL, Ebert MP, Teufel A, Reindl W. Long, relapsing, and atypical symptomatic course of COVID-19 in a B-cell-depleted patient after rituximab. Semin Arthritis Rheum. United States; 2020 Oct;50(5):1087-1088. doi: 10.1016/j.semarthrit.2020.06.013. PMID: 32916559

95. Schramm MA, Venhoff N, Wagner D, Thiel J, Huzly D, Craig-Mueller N, Panning M, Hengel H, Kern WV, Voll RE. COVID-19 in a Severely Immunosuppressed Patient With Life-Threatening Eosinophilic Granulomatosis With Polyangiitis. Front Immunol. 2020;11:2086. doi: 10.3389/fimmu.2020.02086. PMCID: PMC7484740 PMID: 32983161

96. Fallet B, Kyburz D, Walker UA. Mild course of COVID-19 and spontaneous virus clearance in a patient with depleted peripheral blood B cells due to rituximab treatment. Arthritis Rheumatol. 2020 May 26; doi: 10.1002/art.41380. PMCID: PMC7283641 PMID: 32458534

97. Sharmeen S, Elghawy A, Zarlasht F, Yao Q. COVID-19 in rheumatic disease patients on immunosuppressive agents. Semin Arthritis Rheum. 2020 Aug;50(4):680-686. doi: 10.1016/j.semarthrit.2020.05.010. PMCID: PMC7245236 PMID: 32512263

98. Suárez-Díaz S, Morán-Castaño C, Coto-Hernández R, Mozo-Avellaneda L, Suárez-Cuervo C, Caminal-Montero L. Mild COVID-19 in ANCA-associated vas- 
culitis treated with rituximab. Ann Rheum Dis. England; 2020 Aug 7; doi: $10.1136 /$ annrheumdis-2020-218246. PMID: 32769153

99. Daniel P, Raad M, Waked R, Choucair J, Riachy M, Haddad F. COVID-19 in a Patient Treated for Granulomatosis with Polyangiitis: Persistent Viral Shedding with No Cytokine Storm. Eur J Case Rep Intern Med. 2020;7(10):001922. doi: 10.12890/2020 001922. PMCID: PMC7546569 PMID: 33083371

100. Louapre C, Maillart E, Papeix C, Zeidan S, Biotti D, Lepine Z, Wahab A, Zedet M, Labauge P, Tilikete C, Pique J, Tourbah A, Mathey G, Dimitri Boulos D, Branger P, Kremer LD, Marignier R, Collongues N, De Seze J. Outcomes of coronavirus disease 2019 in patients with neuromyelitis optica and associated disorders. Eur J Neurol. England; 2020 Oct 26; doi: 10.1111/ene.14612. PMID: 33103295

101. Meca-Lallana V, Aguirre C, Río B, Cardeñoso L, Alarcon T, Vivancos J. COVID-19 in 7 multiple sclerosis patients in treatment with ANTI-CD20 therapies. Mult Scler Relat Disord. 2020 Jun 15;44:102306. doi: 10.1016/j.msard.2020.102306. PMCID: PMC7295509 PMID: 32585617

102. Thornton JR, Harel A. Negative SARS-CoV-2 antibody testing following COVID-19 infection in Two MS patients treated with ocrelizumab. Mult Scler Relat Disord. 2020 Jun 26;44:102341. doi: 10.1016/j.msard.2020.102341. PMCID: PMC7318946 PMID: 32622338

103. Ghajarzadeh M, Mirmosayyeb O, Barzegar M, Nehzat N, Vaheb S, Shaygannejad V, Maghzi A-H. Favorable outcome after COVID-19 infection in a multiple sclerosis patient initiated on ocrelizumab during the pandemic. Mult Scler Relat Disord. 2020 Aug;43:102222. doi: 10.1016/j.msard.2020.102222. PMCID: PMC7245286 PMID: 32464586

104. Iannetta M, Cesta N, Stingone C, Malagnino V, Teti E, Vitale P, De Simone G, Rossi B, Ansaldo L, Compagno M, Spalliera I, Di Lorenzo A, Landi D, Nicoletti CG, Marfia GA, Andreoni M, Sarmati L. Mild clinical manifestations of SARS-CoV-2 related pneumonia in two patients with multiple sclerosis under treatment with ocrelizumab. Mult Scler Relat Disord. 2020 Oct;45:102442. doi: 10.1016/j.msard.2020.102442. PMCID: PMC7399651 PMID: 32777745

105. Lucchini M, Bianco A, Del Giacomo P, De Fino C, Nociti V, Mirabella M. Is serological response to SARS-CoV-2 preserved in MS patients on ocrelizumab treatment? A case report. Mult Scler Relat Disord. 2020 Jun 22;44:102323. doi: 10.1016/j. msard.2020.102323. PMCID: PMC7307994 PMID: 32593961

106. Novi G, Mikulska M, Briano F, Toscanini F, Tazza F, Uccelli A, Inglese M. COVID-19 in a MS patient treated with ocrelizumab: does immunosuppression have a protective role? Mult Scler Relat Disord. 2020 Jul;42:102120. doi: 10.1016/j.msard.2020.102120. PMCID: PMC7156942 PMID: 32315980

107. Kataria S, Tandon M, Melnic V, Sriwastava S. A case series and literature review of multiple sclerosis and COVID-19: Clinical characteristics, outcomes and a brief review of immunotherapies. eNeurologicalSci. 2020 Dec;21:100287. doi: 10.1016/j. ensci.2020.100287. PMCID: PMC7605741 PMID: 33163634 
108. Suwanwongse K, Shabarek N. Benign course of COVID-19 in a multiple sclerosis patient treated with Ocrelizumab. Mult Scler Relat Disord. 2020 Jul;42:102201. doi: 10.1016/j.msard.2020.102201. PMCID: PMC7227515 PMID: 32480327

109. Maillart E, Papeix C, Lubetzki C, Roux T, Pourcher V, Louapre C. Beyond COVID-19: DO MS/NMO-SD patients treated with anti-CD20 therapies develop SARS-CoV2 antibodies? Mult Scler Relat Disord. 2020 Sep 3;46:102482. doi: 10.1016/j.msard.2020.102482. PMCID: PMC7468278 PMID: 32916509

110. Woo MS, Steins D, Häußler V, Kohsar M, Haag F, Elias-Hamp B, Heesen C, Lütgehetmann M, Schulze Zur Wiesch J, Friese MA. Control of SARS-CoV-2 infection in rituximab-treated neuroimmunological patients. J Neurol. 2020 Jul 11;1-3. doi: 10.1007/s00415-020-10046-8. PMCID: PMC7353821 PMID: 32654064

111. Devogelaere J, D'hooghe MB, Vanderhauwaert F, D'haeseleer M. Coronavirus disease 2019: favorable outcome in an immunosuppressed patient with multiple sclerosis. Neurol Sci. 2020 Aug;41(8):1981-1983. doi: 10.1007/s10072-020-04522-2. PMCID: PMC7305693 PMID: 32564270

112. Wurm H, Attfield K, Iversen AK, Gold R, Fugger L, Haghikia A. Recovery from COVID-19 in a B-cell-depleted multiple sclerosis patient. Mult Scler. 2020 Sep;26(10):1261-1264. doi: 10.1177/1352458520943791. PMCID: PMC7502978 PMID: 32762494

113. Creed MA, Ballesteros E, Jr LJG, Imitola J. Mild COVID-19 infection despite chronic $B$ cell depletion in a patient with aquaporin-4-positive neuromyelitis optica spectrum disorder. Mult Scler Relat Disord. 2020 May 19;44:102199. doi: 10.1016/j. msard.2020.102199. PMCID: PMC7236713 PMID: 32554285

114. Benucci M, Quartuccio L, Li Gobbi F, Damiani A, Grossi V, Infantino M, Manfredi M. Persistence of rT-PCR-SARS-CoV-2 infection and delayed serological response, as a possible effect of rituximab according to the hypothesis of Schulze-Koops et al. Ann Rheum Dis. England; 2020 Aug 4; doi: 10.1136/annrheumdis-2020-218590. PMID: 32753417

115. Schulze-Koops H, Krueger K, Vallbracht I, Hasseli R, Skapenko A. Increased risk for severe COVID-19 in patients with inflammatory rheumatic diseases treated with rituximab. Ann Rheum Dis. 2020 Jun 26; doi: 10.1136/annrheumdis-2020-218075. PMCID: PMC7371570 PMID: 32591357

116. Avouac J, Airó P, Carlier N, Matucci-Cerinic M, Allanore Y. Severe COVID-19-associated pneumonia in 3 patients with systemic sclerosis treated with rituximab. Ann Rheum Dis. England; 2020 Jun 5; doi: 10.1136/annrheumdis-2020-217864. PMID: 32503849

\section{FOOTNOTES}

Submitted March 29, 2021 | Accepted April 26, 2021 | Published May 14, 2021

\section{COPYRIGHT}

Copyright (C) 2021 Pathogens and Immunity. This is an open-access article distributed under the terms of the Creative Commons Attribution 4.0 International License. 